\title{
Report on an \\ Ecological Survey of the Serengeti National Park \\ Tanganyika
}

November and December 1956

\author{
PREPARED \\ for the \\ FAUNA PRESERVATION SOCIETY \\ By \\ W. H. Pearsall, D.Sc., F.R.S. \\ Quain Professor of Botany, University of London
}




\section{FOREWORD}

In January, 1056, news reached the Fauna Preservation Society of proposals to partition the Serengeti National Park, Tanganyika. These were later published by the Tanganyika Government in a White Paper and were reluctantly accepted by the Trustees of the Park.

The proposals did not, however, receive the approval of either the Tanganyika or the Kenya wild life societies, which in their published comments, requested that a committee should be set up to reconsider them. International opinion had also been aroused and a small party, arranged and accompanied by Mr. R. Mr. Arundel, led by Mr. L. Mr. Talbot and sponsored by the American Wild Life Management Institute and the American Committee for International Wild Life Protection, visited the Serengeti. A report on this visit was published by Mr. Talbot, who was then the staff ecologist of the International Union for the Conservation of Nature and Natural Resources.

Meanwhile the Fauna Preservation Society collected much evidence from many sources and proposed to the Colonial Office that, before any changes in the Serengeti National Park were made, an ecological survey of the area should be carried out and an independent inquiry held. The Society stressed the bad effect upon international opinion of the proposed changes and suggested that the matter should be considered at the conference of the International Union for the Conservation of Nature and Natural Resources, which was about to open at Edinburgh. While this conference was taking place, a message was received that the Tanganyika Government was appointing an independent committee to consider the Serengeti.

The whole situation was carefully considered by the Union, and the General Assembly adopted a resolution of its Survival Service stressing the immense value of the Serengeti National Park for the preservation of the finest remaining concentration of the plains fauna of Africa, and welcoming the appointment of the Tanganyika Government's committee. It asked that active co-operation in the field might be given to a small British scientific team, which it was understood might be sent to report on the ecological situation in the Serengeti.

The Fauna Preservation Society accordingly arranged for an ecological survey, which has now been carried out by Professor Pearsall. His Report and Recommendations have been accepted by the Society and are being submitted for the consideration of the Tanganyika Government's Serengeti Committee.

$$
\text { C. L. BOYLE, }
$$

Secretary, The Fauna Preservation Sociely. 


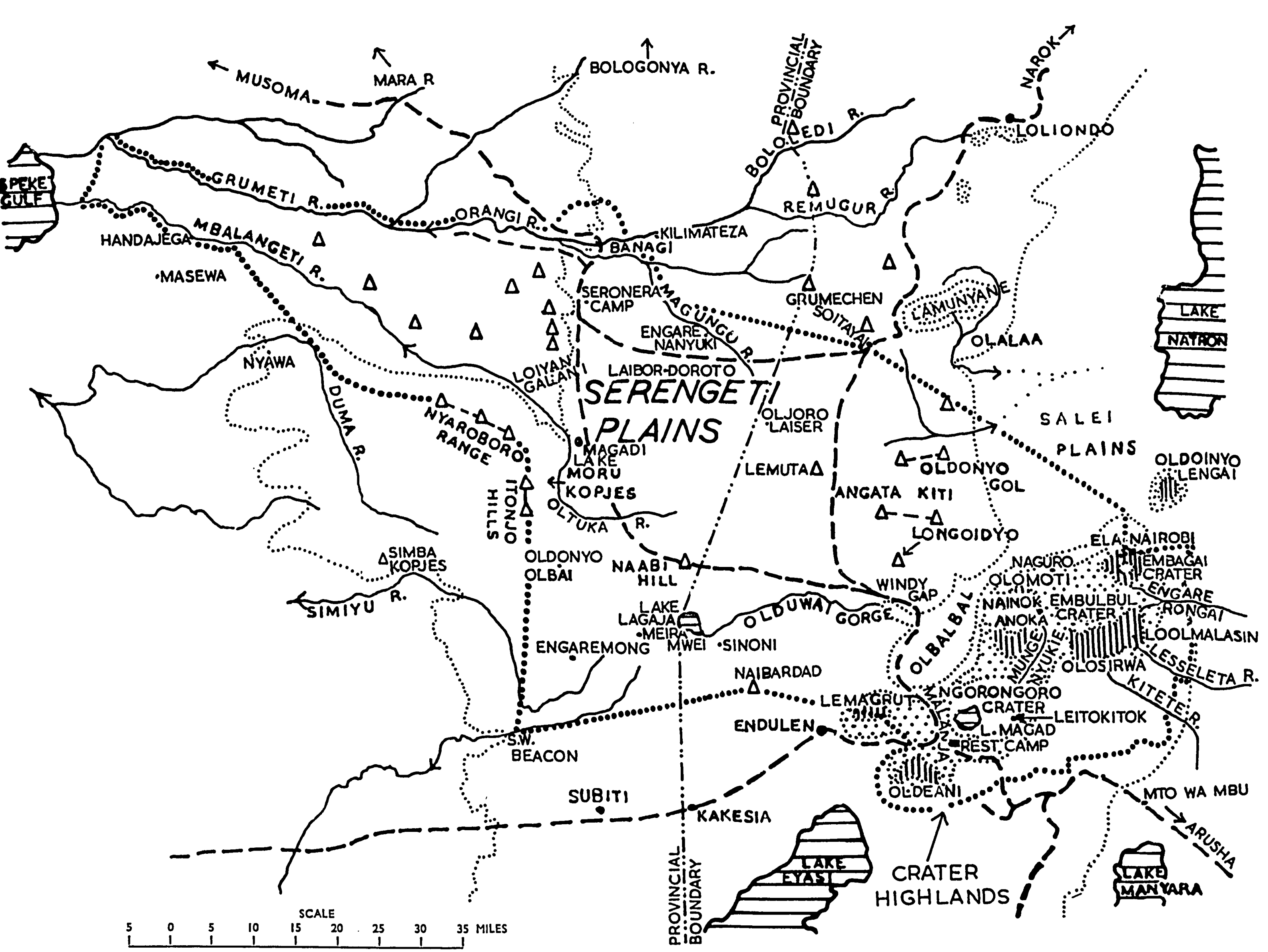

1. GENERAL MAP OF THE SERENGETI AREA.

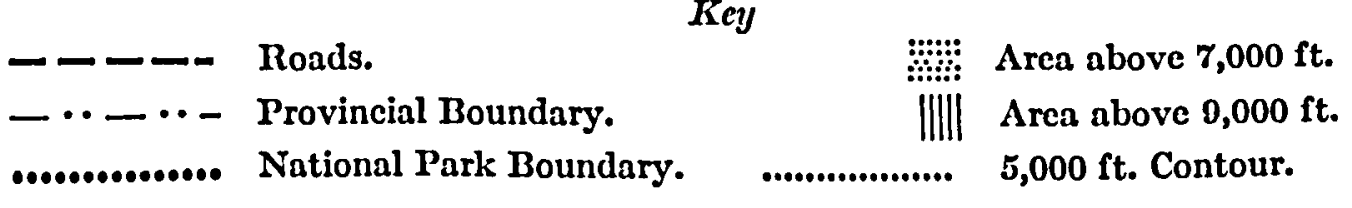




\section{Section 1}

\section{INTRODUCTION}

The region known as the Serengeti National Park is justly famous for the abundance and variety of African game animals found there. It appears to be generally agreed that it is desirable to preserve as part of the essential East African heritage a representative portion of this area, and of the abundance of "plains animals" it contains, such as wildebeest, Thomson's gazelle, zebra and others. Much controversy has, however, centred on the measures taken and proposed to achieve this. As a result I was asked by the Fauna Preservation Society to visit Tanganyika in order to survey the position in the area involved.

It early appeared that the most satisfactory procedure would be to put on record factual statements of what is known which would enable considered judgments to be made. This report therefore consists mainly of sections and maps dealing with salient physical, chemical and biological conditions in the Serengeti.

Most readers will find it sufficient to consider simply the following summary and general considerations.

\section{General Review and Summary}

The area involved is roughly that shown on G. H. Swynnerton's sketch map of the National Park-a triangular area lying between the south-east corner of Lake Victoria (Speke Gulf) and the lines Lake Natron to Lake Manyara and then to Lake Eyasi on the east and south-east. It includes three main types of country :. (i) to the west rather broken and hilly country with three main river valleys running in a generally westerly direction to Lake. Victoria (Rivers Grumeti, Mlbalangeti and Duma); (ii) a higher plateau of barely undulating plain covering about 1,000 square miles between 5,000 and 5,500 feet, the Serengeti Plain proper; (iii) the Crater Highlands-a volcanic block mostly between 7,500 and 8,500 feet but rising to six peaks of from 10,000 to 13,000 feet. 'The eastern limit of this block is a perfectly natural boundary, the escarpment of the Rift Valley.

The three areas are geologically different-the hilly west composed of ancient granitoid rocks (the " granitoid shield ") with here and there a cap of Bukoba sandstone. In the central plain, the granites appear only as small isolated bosses of rock, the rock being overlaid by a great depth, locally up to 400 or 500 feet, of more recent sedimentary materials, mainly volcanic ashes or 
limestones often deposited under lacustrine conditions. One volcano, Lengai, is still active, and dust carried from it is still being deposited at intervals (six times in the last forty years) on the eastern part of the plains. Although these areas have a dusty and easily-eroded surface, the soils appear to have greater potential fertility than those further west (Sections 5 and 6 ). The Crater Highlands are composed mainly of dark-coloured Tertiary volcanic rocks with local ashy deposits. They are remarkable for a series of "craters" which are usually of the cauldron type, presumed to be caused by the cone of a volcano sinking into the molten matrix below. The most spectacular of these is Ngorongoro, some 15 miles across and 2,000 feet deep, on the rim of which the headquarters station of the National Park is situated.

The rainfall is normally torrential in character and much may be lost by direct run-off immediately after fall and by the high evaporation rates. It is strongly seasonal-" short rains " about December being followed by a main rainy season in April-June, during which period transport is difficult or impossible.

In addition to the low rainfall and high evaporation rates over the area as a whole, the Serengeti plains are marked by great uncertainty of rain so that biologically they must be regarded as a famine area (Section 4). 'The three areas so distinguished on geographical and topographic grounds have different vegetation (Section 6); the western Serengeti mainly bush with corridors of grassland running parallel to the rivers and wide alluvial plains near Lake Victoria, which serve as dry season grazing for plains animals : the Serengeti plains, with very deep soils and uncertain rainfall are dry grasslands, verdant only in the wet season, their water supply being too scarce and too saline to be adequate for use in the dry ; the Crater Highlands rise from these grasslands through Acacia scrub to mist-forest and mountain-heath, but most of the original vegetation has been modified by fire and grazing, yielding widespread grasslands which form the main dry scason grazing of the Masai and of a portion of the plains animals. Many of the grasslands, both upland and lowland, arc in poor pastoral condition, and soil crosion is widespread.

All these regions are marked by low rainfall, high temperatures and very high potential evaporation and in the Crater Irighlands alone are there conditions of low temperature and shaded ground over considerable arcas under which water can be stored to provide permanently for flowing springs and streams suitable in quality for prolonged use. There is urgent need for the conservation of the water catchment areas (Section 11). 
In these three types of country there are to be considered the rival claims of wild animals (mainly herbivorous) and of the Masai and their stock. Both need to use seasonal grazing and both require water and for both of these requisites there must be competition (Section 3).

In seeking a permanent settlement of the Serengeti problem it appears that three principles must be accepted :-

(i) The game population must be provided with a unit enclosing a sufficient area to include the whole of their periodic cycle of movements and, moreover, one which is capable of being permanently maintained as such a cyclic unit.

(ii) Increased competition between game and Masai when in the same area is inevitable (Section 3).

Hence, they should ultimately occupy separate territories each suitable for their somewhat different needs.

(iii) In a country like the Serengeti, most of which is marginal to human occupation, the allotment of territory to particular competitive uses is primarily a problem of the most suitable forms of land-use in a given area. If permanent solutions are to be found, they must take account of the diverse ecological potentialities of the area; and development must be based on these potentialities.

The application of these principles must take into account certain facts.

(a) The study of seasonal game movements (Section 2) suggests that the minimum viable unit for the preservation of a large concentration of the plains game would be bounded. approximately by the existing park boundary on the north, by the Duma and Simiyu rivers in the south-west, the Olduwai river and the Olbalbal-Loliondo road on the south-east. In this area it would be necessary that scientific interests should be predominant.

(b) The largest Masai population in the Park area uses the Crater Highlands (Section 3). It is therefore logical and economical that development of Masai interests should be concentrated in this and the surrounding area. In addition, this represents the territory of highest water and soil potential (Sections 4, 5 and 7). Roughly, this would be the existing main grazing areas in the highlands, the area east of the Loliondo-Olbalbal road and north of the Olbalbal Pond, and the area south of the Olduwai. In this area, human interests would be paramount. 
Limitations are necessary to meet two points :-

(1) Water is vital to the whole of the Serengeti. The permanent water is concentrated mainly in and around the Crater Highlands. Its conservation to the utmost degree must clearly be a first consideration. To this end the higher parts of the area and those still wooded should be strictly preserved against fire and grazing and as far as possible be maintained as forest, reafforested, or kept under an appropriate shade-cover.

(2) The National Park Camp at Ngorongoro has involved considerable capital expenditure both in money and in labour and can hardly be scrapped easily. It depends for its success on scenic attractions of the Ngorongoro Crater and on the presence of wild animals, big game, in and around it. The first decision clearly required is whether the Camp should be maintained or whether it should be scrapped and the capital investment written off. If the former is approved, the existing numbers of plains animals, especially wildebeest, would suffice and in order to maintain them it would be necessary to keep a corridor for their movement to and from the Serengeti Plain. It appears this can only be done with some agreed restriction of Masai activities in the Crater and the Malanja region, along the western edge of the Crater. The preservation of the forest animals would be safeguarded by the reservations under $(b)(1)$ above.

The conditions under which a solution along these lines is likely to be permanent should be clearly realized. The first is that they depend on firm control of the areas involved towards the desired end. The second is that the whole question of development of Masai-occupied territories should be considered systematically. 


\section{Section 2}

\section{GAME MOVEMENTS}

The essential part of any proposals to preserve game must be that a viable unit is created in which the appropriate animals have full scope to behave in a normal manner. The boundaries of the reserve area must be based on the known lines of migration

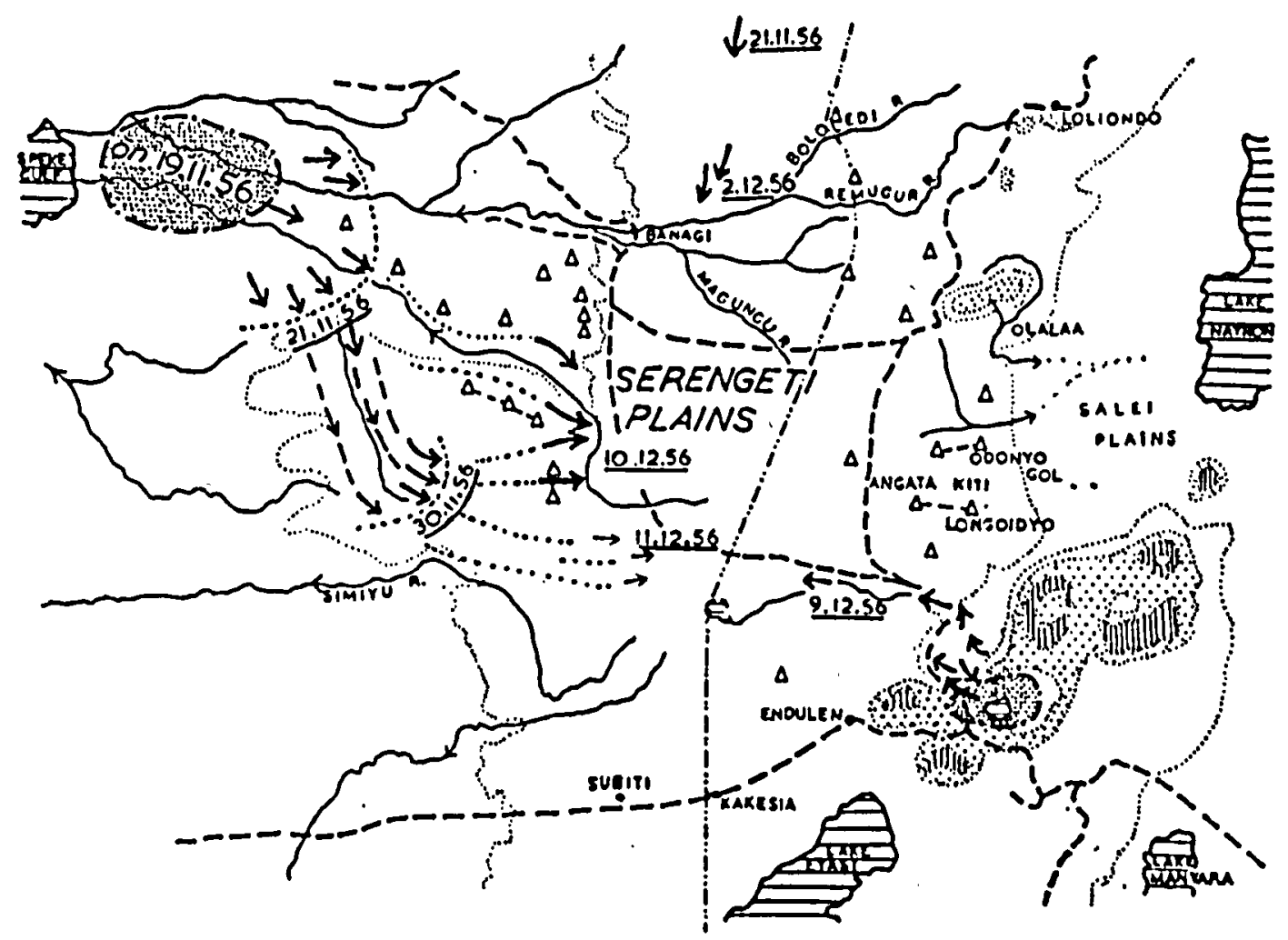

2. GAME MOVEMIENTS, DRY SEASON 1050.*

The henvily stippled arens show where there were henvy concentrations of game in the dry season at the end of 1050. The arrows show lines of movement and positions reached on the dntes indicated.

of the plains animals and on the habits of any representative species present in smaller numbers. As no integrated statement of the movements of game was available, the distribution of the plains animals was observed at the end of the dry season in 1056, and the movements from these dry season concentration areas was followed. The main facts are recorded in maps 2 and 3 . The largest concentrations of wildebeest and zebra were found in the lower reaches of the IIbalangeti and Grumeti where there are

* 'This map may be used in conjunction with the folder opposite page 1. 
alluvial grassy plains. There was a considerable concentration in the Ngorongoro Crater and a northern concentration of unascertained size towards the Bologonya river. Owing to the fact that operations against Mau Mau made the latter a security area it was not possible to examine the northern concentration fully and it requires further investigation. The subscquent movements

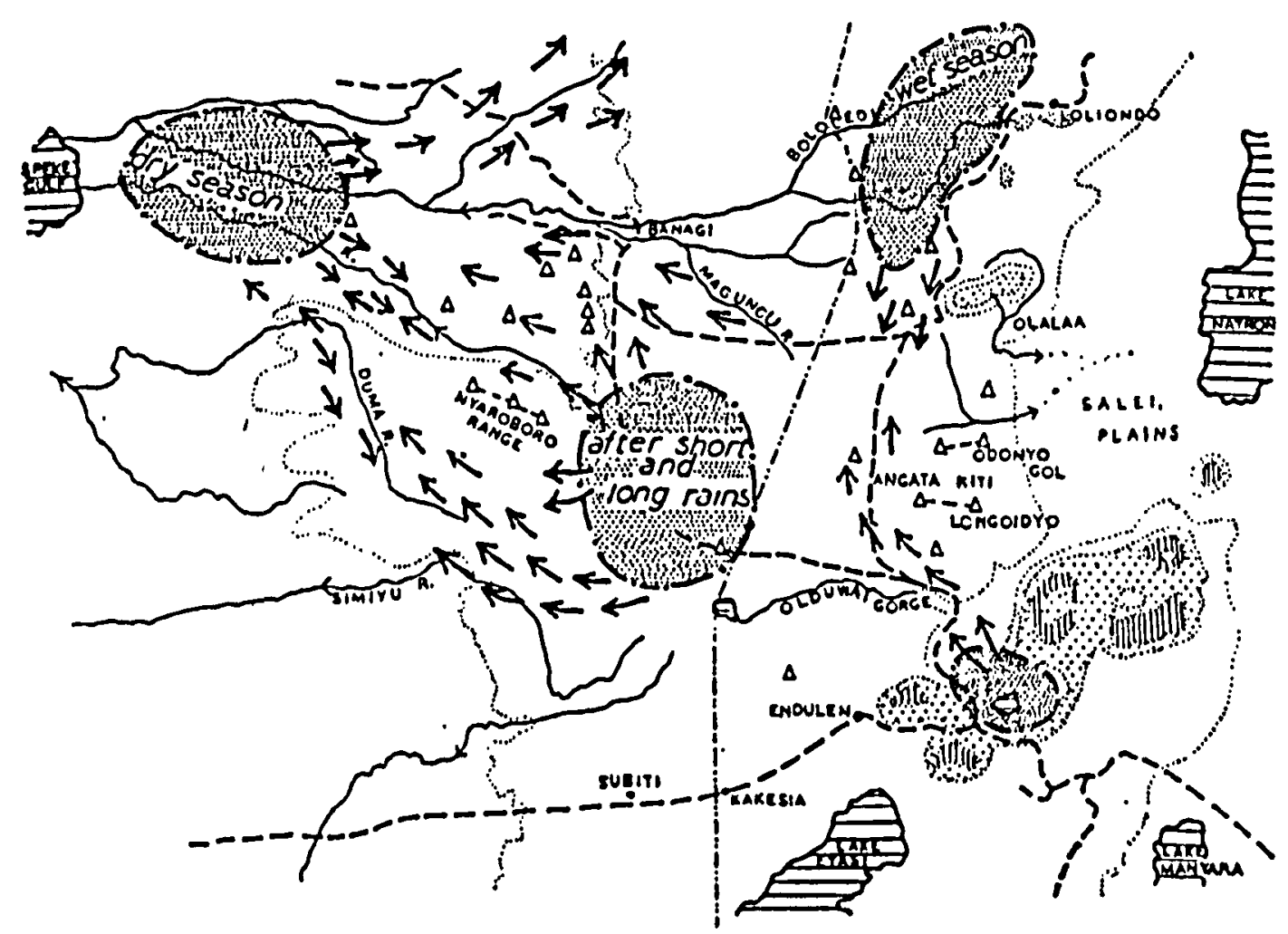

3. GANE CONCENTRATIONS AND MOVEMENTS 1052-50.

Important game concentration arcas during the period 1052-50, shown as henvy stippling. The arrows indicate lines of game movement immediately nfter the concentrntions.

from these areas were all observed. Starting about 19th November, the main movement from the west took place as shown on the map south of the Nyaroboro range along the line of the Duma river. 'This was seen at various intermediate points until finally large numbers of zebra and wildebeest were observed (on 10th December) emerging on to the plain through the gaps in the hills just north of the Moru Kopjes, at the same time a considerable number (several thousand) had reached the area between Oldonyo Olobai and Naabi Hill. The movement southward of smaller numbers of game, again wildebeest and zebra, was 
observed (21st-30th November) in the corridor west of the Provincial boundary along the Kilimafezha-Narok track. Several movements of wildebeest from the Ngorongoro Crater into Olbalbal and back were observed. These were finally followed by a large movement west, north of Olduwai river (9th December). What happened to these animals was not determined, but Dr. L. S. B. Leakey states that this is a normal line of movement, these animals calving just east of Naabi Hill. It is agreed that many wildebeest usually calve in the Ngorongoro Crater. To some extent, the initial movements of game animals seem to be determined by the distribution of the early rains. These started to the south of the Nyaroboro range in December, 1956, and this might account for the first game movements being in that direction. However, the configuration of the ground and the direction of prevalent wind (north-east) both make it probable that 1950 was in no way unusual in this respect.

The more normal movement of wildebeest during the preceding five years appears to have been equally on both sides of the Nyaroboro range, while the general tendency towards large concentrations in the western Serengeti around the Moru Kopjes was observed. 'The western animals appear to breed in this locality and then to spread during the wet scason over most of the open plain as far as the Lemuta Hill. They are normally joined by large numbers of animals which appear to come from a dry season concentration area in the Bologonya region. In normal years the dry season concentration in the Crater Highlands appears to move down into the Olbalbal, and then to move north-west on both sides of the Lemuta Hill, though this movement was not actually observed in 1956. Some of these animals were formerly believed to move into the Salei plains, but it appears that this movement has now practically ceased. Two maps are appended recording observations made by specific observers. In regard to map 2, no material concentratian south and west of Loliondo was observed in late 1956, the end of the $d r y$ season. The ret season concentration shown in this area was stated by different observers to be "a smaller one" and a "diminishing one". If this area were developed pastorally, there is a reasonable probability that these animals would move west of the Provincial boundary, or remain on the main Screngeti plain.

The above paragraphs refer mainly to wildebeest and to zebra which usually accompany and precede them. In December, 1956, large herds of zebra emerged on the Serengeti plain one or two days before the main wildebeest population. While most bands 
of wildebeest are preceded by small groups of zebra, most of the observations in 1956 were based on wildebeest because they can be most easily seen from the air and with binoculars from a distance. Some observations were made on impala. Isolated individuals of this species occurred at the end of the dry season all through the bush country and on the west of the main plain area. There was a concentration in the bush just south of the hill Handajega, where large numbers of impala with newly born calves were seen. There is evidence that this area is an important breeding ground and as such it should be included in the area reserved for game preservation.

Thomson's gazclle moved out from the bush area on to the plains some days before the zebra and wildebeest. $A$ similar movement was seen also from the Crater Highlands and very large concentrations were observable between the Olduwai and Lemuta Hill in early December. The subject of the scasonal movements of Thomson's gazelle has been studied by Mr. A. C. Brooks, Colonial Research Fellow, and the following account of the movements is taken from his report, which deals with the years 1051-54 (unpublished). At that time a large wet-season concentration occurred on the Serengeti plain and a small one just west of Loliondo. The main migrations from this area were down into the corridor between the Grumeti and Mbalangeti rivers. A smaller one went north towards Loliondo, a second considerable one into the Ngorongoro Crater and finally another one south-west towards the Simiyu River. It is evident on examining Mr. Brooks' summarized data that considerable concentrations could also occur during the dry season in the Mbalangeti corridor when the animals were absent, or nearly absent, from the whole of the castern Serengeti. There is cvidently some variation in the concentrations at different places from year to year. As to the breeding sites, these animals drop their fawns on short grass areas on the plains during January and February.

An attempt was made to estimate the number of 'Thomson's gazelle on the Screngeti plains during the short rains of 1953. The census counts made on motor car traverses of the plains by experienced computors gave an estimated population (with an crror of about 10 per cent) of approximately 180,000. No such figures are available for other game animals, but as a very rough estimate of the relative numbers of wildebeest present at the end of the dry scason in 1956, this would be of the order of 10,000 in the vicinity of the Ngorongoro Crater and possibly at least ten times this number in the concentration area at the west of the 
Mbalangeti corridor. The numbers seen further north towards the Kenya border in the Bologonya River area did not exceed 1,000 , but this number is probably too low as the survey, for reasons stated, was extremely incomplete in that area.

The survey emphasized the importance of three western areas in the dry season movements, viz. the lower Grumeti valley, the corridors on either side of the Nyaroboro Range and the Mroru concentration area. The unit so defined seems to indicate main centres required as a game reserve. More information is required about the northern movements which also seem important. 


\section{Section 3}

\section{POPULATION}

Most of the western bush country and the corridor of bush country west of the Provincial boundary and north to the Kenya border, the Bologonya River, is not occupied by any significant human population or cattle as it is tsetse country. There is a small inflitration of cultivators just south-east of Handajega, along the main line of migration of plains animals in 1956. No permanent occupation was observed in the area lying south of the Nyaroboro range as far as the line of the Simba kopjes and the Simiyu River. 'This, however, appeared to be a poachers' paradise, as six newly dug game pits were observed from the air and four lines of trap fencing, spread over a very considerable area. Iruman occupants are penetrating into almost every area in the Crater Highlands, including the woodlands. What appear to be most recent penetrations occur in considerable numbers immediately south of Oldeani, in small numbers between the Kitete and Lesseleta rivers on the south-eastern flank of the Crater Highlands, and very largely in the woodlands lying cast and south-east of the Embagai Crater. Fifty-two huts were counted in the Embagai Crater itself, where a very considerable occupation has developed. The north-western flanks of the Crater Irighlands bear all the signs of long-established human occupation.

Any attempt to represent the distribution of the population must assume that Masai occupants are more or less permanently in the arcas shown, and to some cxtent this must be true. Although they may not be permanent occupants on a particular site they constantly return to the same site and therefore the effects of occupation are in fact almost as though the occupation were permanent. The migratory habits of the Masai appear to be less pronounced in this area than they are clsewhere, and most of the movements on which definite information could be obtained secmed to be comparatively short distances. An occasional movement over a longer distance as reported appenred to apply to newcomers who are not normally occupants of the arca and must be received with some caution.

It appears that the wet scason movement from the Crater Highlands is of relatively short duration and confined to the period of rains. In most cases part of the population, the old men and maidens, may remain behind while the main portion moves to wet scason grazing. 
The Olduwai MIasai apparently move entirely from the plains around Olduwai before the rains begin and when the influx of wildebeest is due.

Full details of the human occupants in the Park in 1054 have been given in a report by H. S. St. J. Grant (11).* This report did not include occupants in the Olduwai region, who on the basis of their cattle population might amount to about one-fifth of the population of the rest of the Park area. If this were so, the total population would be of the order of 21,000 men, women and children. On the basis of the figures given by Grant, there are about 900 residents along the western edge of the plains (i.e. the bush margin and the line of kopjes and water-holes leading from the Engare Nanyuki to MIoru).

Of these, some $\mathbf{3 0 0}$ may be considered to have claims to represent pre-1940 residents. The remainder are said to derive mainly from the area towards Loliondo, east of the Provincial boundary.

A measure of the effective occupation is also available from data for the livestock population of the National Park area and its surroundings (Pullon, "Data on Livestock Populations," unpublished). It appears from these sources of information that, on an average, about 120,000 cattle are present in the area as well as donkeys, sheep and goats. Of the cattle, about 20,000 are commonly found in the dry season in the plains area of the Park, the remaining 100,000 occupy the Crater Highlands. Although the details differ a little the actual figures do not seem to vary much as far as they are available for both the dry season and for February and MIarch. The Moru area, one of those which it is proposed to excise from the National Park, is said to have contained nearly 6,000 head of cattle in the dry season of 1952, about 8,700 in February, 1953, with 11,000 near Seronera, and 25,000 for both Moru and Seroncra in March of 1954, the beginning of the wet season. At the end of the dry season in 1950, the numbers as estimated from the air were probably not more than four or five thousand, near MIoru, with a similar number near the water-holes in the Seronera area.

If the cattle numbers have shown a tendency to increase this is thought to be due to recovery from the drought around 1040 . Figures are not available for the Park aren on a comparable basis until 1950-54. Those made available by the Veterinary Department are given in the table on the next page.

The total numbers in the whole of Masai-land are believed to have reached 700,000 to 750,000 in $1930,1941-42$ and 1955 , falling after the drought years 1032-33 and 1040 to about

* Sec List of Documents Consulted, page 01. 
Nuabers of Catrue in Thousands in National Park Area

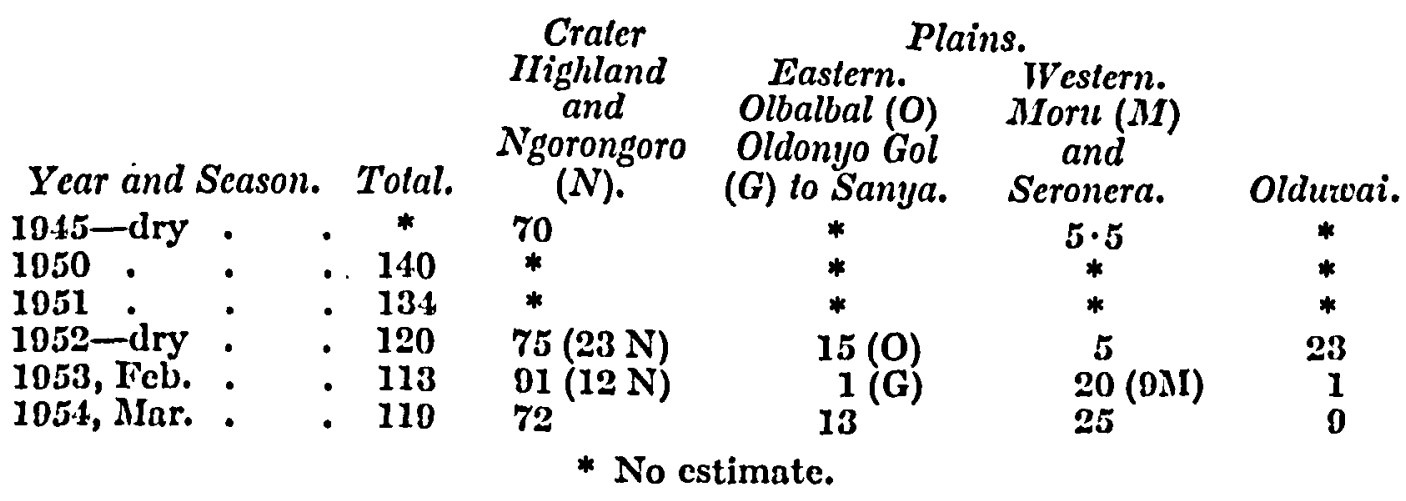

500,000 . The cattle population in the Park has been relatively static during 1950-54. Drought is assumed to limit the population as mortality from rinderpest has been climinated by mass inoculation from 1941-42 onwards.

The figures for small stock are :-

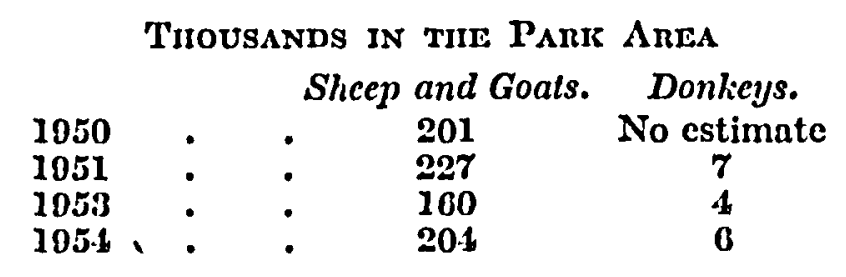

The annual sales of cattle amount to about 5 per cent, according to figures given to me by Mr. G. Ashley, District Oflicer, Ngorongoro.

The figures suggest that the stocking has reached nearly a steady level, and that the 5 per cent of sales suffices to account for the natural rate of incrense.

Two other points should be considered in connection with problems of human occupation. It secms quite certain that the tendency will be for pastoral peoples to become permanent ranchers as the pressure of land increases and freedom of movement decreases. Secondly, any present distributions based on the existence of discase are no doubt likely to disappear as improvements in the scientific control of discase take place. It is for these reasons that emphasis should be laid on existing occupants as likely to become more static, irrespective of the presence or absence of eattle or human disease at the present time.

Tire Masai and 'Tiem Ecological Influence

It scems necessary at some stage to consider the influence of the Masai on conservation problems in the Serengeti region. It 
is advisable to start by disclaiming any intimate knowledge of this people. Of the various papers referring to them, I have accepted, as a summary of their history since A.D. 1900, a paper prepared by Mr. H. St. J. Grant and seen in draft. This seems to be an admirable and impartial factual account, written sympathetically by one who has worked among them ("The Masai in the National Park," unpublished). The attitude adopted here, however, is simply to regard them (and their cattle) as migratory inhabitants of the region, and to try to assess dispassionately their status in the general ecology of the areas they visit.

The reader may first be reminded that it is almost universally the case that herded animals do more damage than wild game of similar requirements, and in similar numbers. Damage from trampling and overgrazing is inevitable when stock are continually brought back to the same places-watering-places or stockyards. Also their gait is different and the mere fact of continual herding make them habitually move in long lines and keeps them from dispersing widely over the plain. Thus, the pastoral mode of life of the Masai is inevitably, if locally, harder on the grasslands than the presence of a similar number of game.

It is noticeable that while the Masai are accused by some of causing serious overgrazing and soil erosion, others even commend them for employing proper methods of land-use, moving their cattle towards a water-hole on one day and away from it on the subsequent one. The truth lies probably between the two attitudes. The Masai, like most other experienced graziers, have learnt to spread the grazing effect a little but are, as is common among pastoralists white or dark, practically indifferent to any but the most immedinte results of grazing. They are thus probably no worse, or no better, than any of those all over the world who have exploited and are exploiting pasture and woodland without thought for the future. The significant point in this connection is not so much the question of whether the MIasai are good or bad pastoralists or land-users, but that over much of this area they are operating in tension zones in which the adverse effects of heavy grazing and cattle trending are liable to be especially severe..

It is in precisely this type of country, throughout North Africa, Middle East and India, that uncontrolled grazing is known to have produced a sort of ecological rake's progress-cattle grazing on open pasturable woodlands (overgrazing preventing the regeneration of the woodlands and leading to croded and nutrient-poor soils and grasses of low nutritive status), sheep 
and goats introduced because they can graze closer on poorer vegetation-further degeneration leading to semi-desert where only goats (and camels) can be kept.

Against this type of indictment, little or no defence of the Masai is possible. The Moru Kopjes and the fate of the granite bosses in the plains parallel the reckless destruction of woodland margins seen all over the Crater Highlands and evident wherever the Masai are occupying or have occupied partly wooded country. The available evidence has been given as to the effect of this on the water reserves (Section 7).

On the grasslands, the striking effects of overgrazing-pasture deterioration, soil compaction and crosion-are seen mainly near water-holes and it may not be altogether fair to regard the Masai as entirely responsible, for most of these areas must have been used by pastoralists for a very long time, since Neolithic days in the case of some of the most damaged, e.g. around the Engare Nanyuki and Olduwai water-holes. What is clear, however, is that any further increases in the numbers of the Masai and their stock is likely to introduce further and finally destructive detcrioration and that remedial measures are generally desirable even at the present level of occupation. Around the most used water-holes pasture and soil conditions already approach the semi-desert.

It must be assumed that the Masai and their stock will in general tend to increase in number rather than decrease, for any limitations in the present numbers due to disense, either human or animal, will be removed in the future, if past experience can be taken as a guide. Even where the Masai cattle alone are using the grasslands there is evidence of grassland deterioration and it scems clear that it would not be possible for both cattle and game to occupy the same areas permanently.

An increase in occupation numbers would be likely to have further adverse effects on the game. It has often been said that one may see Masai stock and game grazing within a short distance of one another and this is true enough. Nevertheless, the tendency is for the presence of Masai and their stock to exclude game. This is very apparent in the main Masai-oceupied parts of the Crater Highlands where game is scarce. Grant (" The. Masai in the National Park," unpublished) also observed this. During the present survey a more striking illustration was given by the occupants of the Malanja, a valley corridor leading from the west of the Ngorongoro Crater to the plains. This was scen on eight scparate occasions during the survey. On four occasions only Masai and their cattle were present, on three only 
wildebeeste and zebra were grazing there. Only on one occasion were a few game present as well as Masai cattle.

It would seem, therefore, that if partial development of the Screngeti area is required, it will be advisable to separate the two main interests as far as is possible, considering some areas for game reserves and as mainly of scientific importance and devoting others mainly to grazing with worthwhile methods of range control and grassland improvement.

One other point remains to be mentioned. Almost every paper on the subject of the Serengeti refers to the rights of the MIasai in this area. None that I have seen mentions any duties or obligations or in any way defines the status necessary to exercise these rights. There is no question that this is an impossible position in a National Park or in any useful form of nature reserve. It will be necessary, if Masai are to graze in such reserve areas, to vest the grazing rights in individuals (such as the head of the family or tribe) who can be held responsible for damage. The creation of personal rights in this way could satisfy the legal position, limit possible further encroachment and allow of ultimate financial compensation if a modification of the reserve status were necessary.

Further, however, experience elsewhere shows that land rights held in common wherever the number of commoners is large, are a barrier to improvements in land-use. A Royal Commission is now considering this problem in Britain. Thus, English and Welsh common lands are notorious examples of land held for grazing which has deteriorated beyond the limits of present usefulness, because with an undefined number of proprietors no one will incur the cost of labour or of any improvements. It is only when an individual or a limited number of definable individuals holds land that improvements can be effected. The position developing in the Serengeti is thus such 'as to prevent any scrious attack on the problems of land-use it presents. Furthermore, it must be apprecinted that large parts of the Serengeti have no future for increased grazing or ranching unless the seasonal distribution of grazing is adequately controlled and more advanced methods of range manngement are introduced and used. 


\section{Section 4}

\section{WATER}

Whether one considers the needs of the vegetation, of the game or of the human occupants and their cattle, it is apparent that water supplies are fundamental to any attempt to preserve or develop the possibilities of the Serengeti region. Considerable attention has therefore been devoted to the different aspects of this subject and the data are assembled and discussed under the headings (i) Rainfall and evaporation; (ii) Permanent water supplies-their distribution and quality; (iii) Water conservation.

\section{(i) Rainfall and Evaporation}

The rainfall is normally torrential in character and much is lost by direct run-off immediately after fall. It is strongly seasonal"short rains " about December being followed by the main rainy season, April-June, during which period transport is difficult or impossible. The rainfall data are scanty and often of too short duration to be more than indicative. The most useful ones come from outside the present park area and, taken with others available, suggest a general average of $30 \pm 2$ inches per annum. This applies to places as far apart as the Speke Gulf $(3,717$ fect) and Nainokanoka $(8,700$ feet).

The only very low rainfall record is from Olalaa (averagc 22 inches), a figure which probably reflects the dry conditions to the east, whence the prevalent winds come, rather than the effective rainfall condition on the hills behind in the west. There the frequent cloud cover and morning mists suggest a much higher rainfall (say 30 inches), an indication borne out by the character of the vegetation. 'The two high rainfall records (about 35 inches per annum) come from Oldeani (on the south-east of the Crater Highlands) and Ngorongoro.

The pertinent points in assessing the elimatic conditions are undoubtedly two. The first is the uncertainty of rain in the central plains area. According to the Glover map (30) this area is likely to get less than 20 inches of rain in about one year in four. It is, in short, biologically a famine area. This generalization undoubtedly expresses an essential feature of the plains climate. The distribution of cloud-cover alone, but also that of the vegetation and of the very local and intense storms during the " short rains", all show a marked contrast with the western hills and the vicinity of the Crater Highlands. 
TABLE 1

Water ANalyses in tite Serengeti Reatos (28.11.50 to 4.12.50) As P.P. MiLt.

Weslern Rivers.

1 Magungu river at Banagl, 20.11.50. 2 Arbalanget1 river at Ilandajega,

3 Duma river at Kitu Hil, $30.11 .50^{\circ}$.

4 Kirawlra, Grumetl rlver (approx. 15 milles above Junction with liuwana river), 1.12.56. . .

Granite Outcrops.

5 Eagle Kople (approx. 8 mlles E.N.E. trom Naabl IIII), 3.12.50

0 Mroru.

Plains.

7 Seronera rlver (upper drift), 3.12.50

8 Iolyangalanl river (road drift north of Aragad IIIll), 3.12.50

0 Oltuka river (road dritt south-cast of Magadl Iake), 3.12.50

10 Oltuka well, 3.12.56

11 Oljoro lniser I, 2.12.50

12 Oljoro lnlser II, $2.12 .50^{\circ}$ :

14 Sinonl, upper Olduwal, 4.12.50

Volcanic IIills.

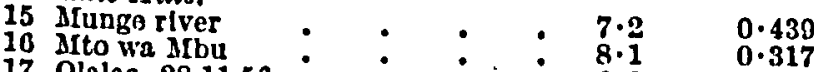

pII. Conductivity

Carbonate Chloride Fluoride
CO,p.p.m.

17 Olalas, 28.11.50: $: \vdots: \quad \bullet \begin{array}{ll}8.1 & 0.317 \\ 0.8 & 0.582\end{array}$

\section{$1 \cdot 240$}

$0 \cdot 0$

$0 \cdot 1$

$0 \cdot 5$

$7 \cdot 0$

$\mathbf{0} \cdot \mathbf{2}$

$7 \cdot 8$

$8 \cdot 1$

$0 \cdot 4$
$7 \cdot 5$

$8 \cdot 5$

$8 \cdot 7$

$\mathbf{8 \cdot 2}$
$0 \cdot 250$

$0 \cdot 380$

$0 \cdot 100$

0.210

$0 \cdot 771$

3.050

$1 \cdot 585$

$13 \cdot 580$

$1 \cdot 358$

$0 \cdot 506$

$5 \cdot 704$

$5 \cdot 503$

$2 \cdot 503$ traco

115

$1 \cdot 0$

nIl

nll

nll

nIl

nil

$1 \cdot 1$

$1 \cdot 0$

nll

$1 \cdot 1$

nil

nil

trace

$1 \cdot 3$

$1 \cdot 0$

8.0

nll $\quad 02 \quad 0.0$

nil

nil

300

720

150

\section{8}

35

35
075

469

345

115

62

$4 \cdot 2$

42

$16 \cdot 5$

$\mathbf{2 3} \cdot \mathbf{5}$
$\mathbf{2}$

nil

nil

nil

nll
n!l
27

$2 \cdot 1$ $0 \cdot 3$

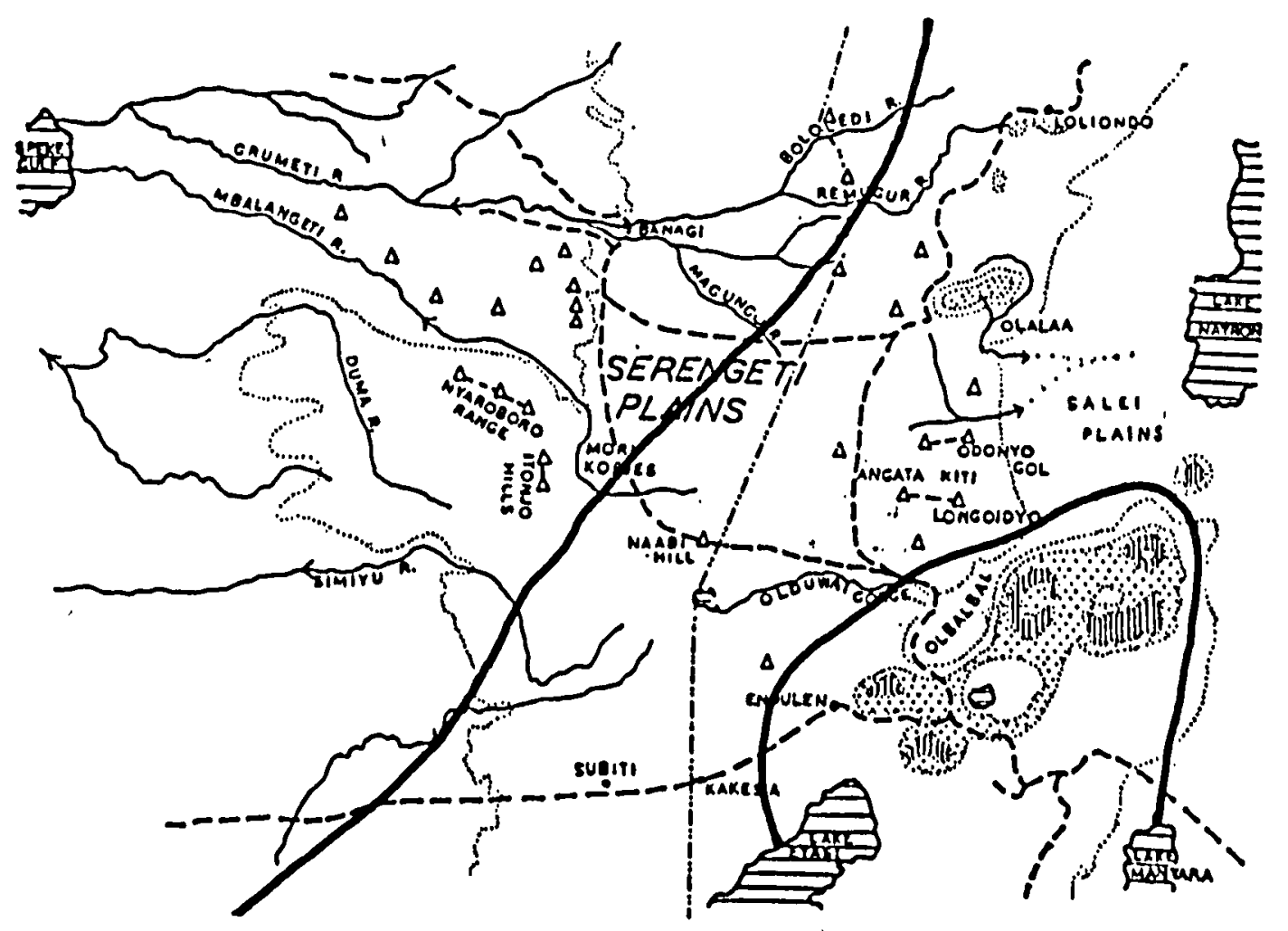

4. DROUGIIT AREA.

Between the two henvy lines there is the probability that the rainfall will not reach 20 inches in one year in nve. 
The second important factor climatically is undoubtedly the variation of evaporation rates associated with changing altitude and with the falling temperatures at greater heights. In general, the rainfall is inadequate to compensate for the potential evaporation rate which, by comparison with other regions, must be at least of the order of 50-60 inches per annum on the plains. This was the estimate given by C. Gillman (17) for potential evaporation from water surfaces at the level of Lake Victoria.

The evaporation rate, however, must depend very largely upon the temperature of the evaporating surface (as well as on air

Summarized Avamlange Evaporation Data (Piche Evaponimeter), Calculated Potential Evaporation and Annual Rainfald for Stations in Tanganyika at Different Altitudes

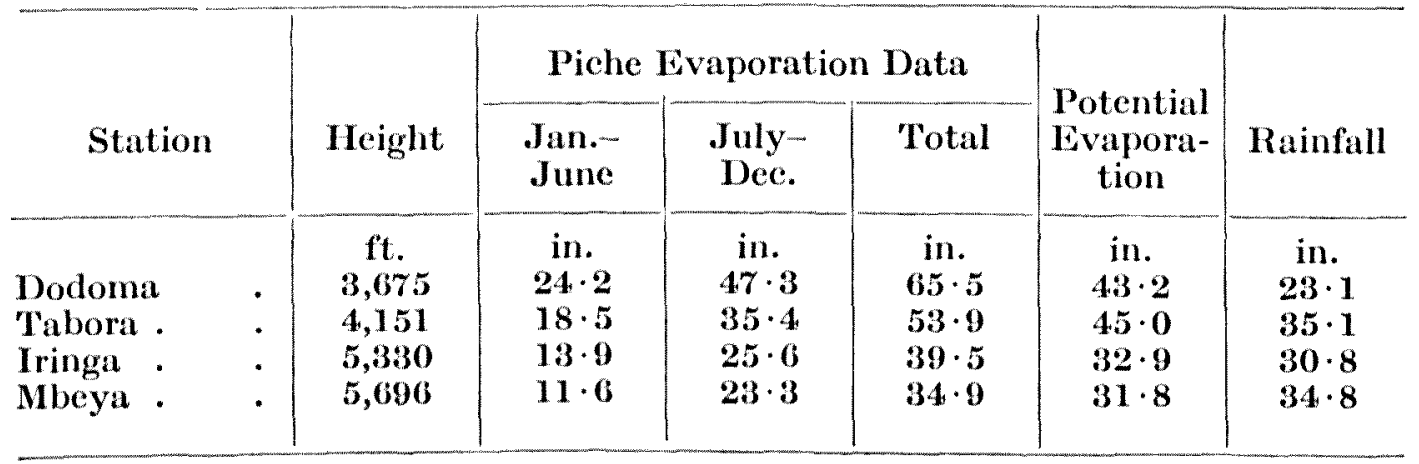

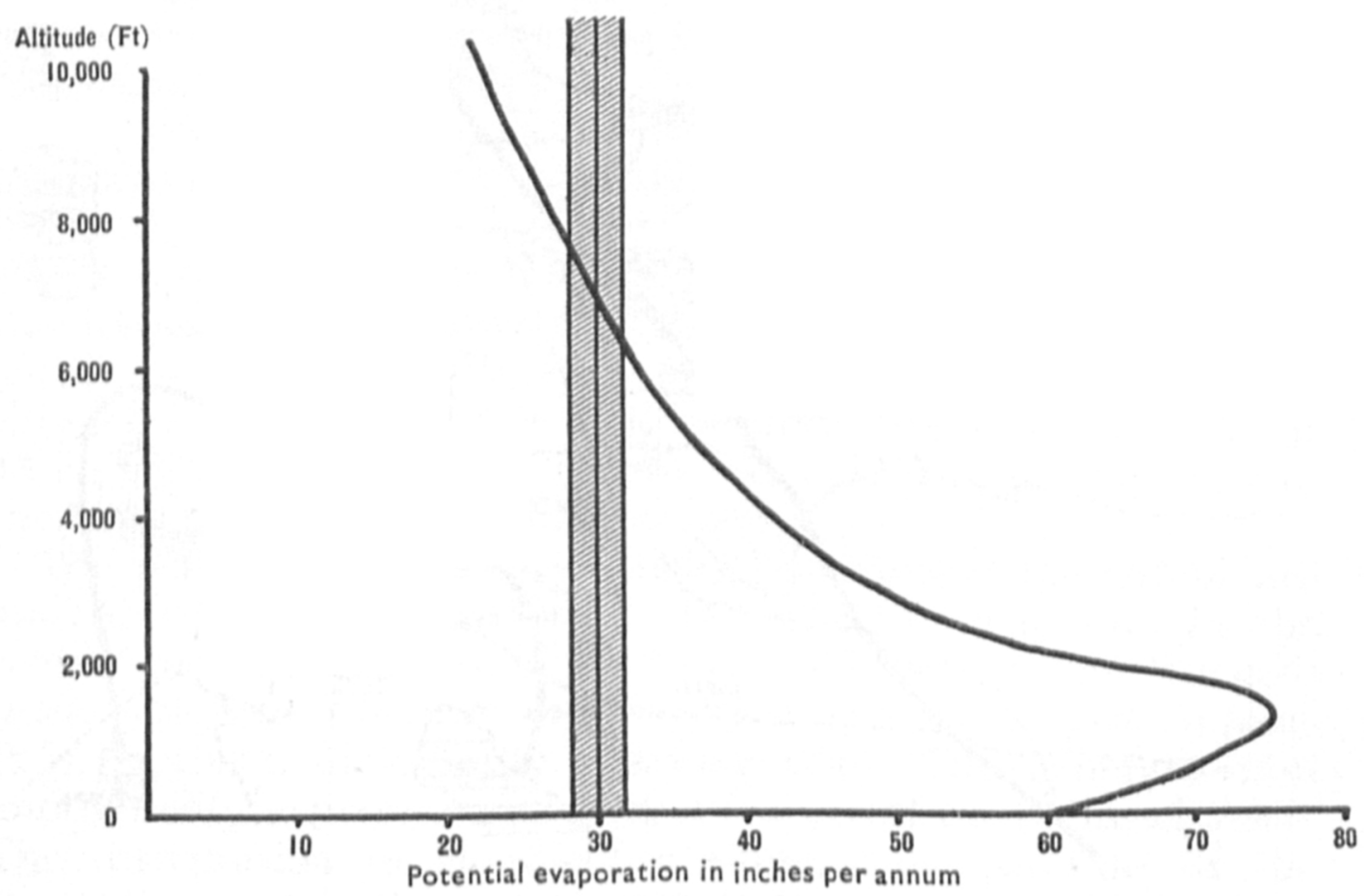

Fra. 1. - Potential evaporation at different altitudes in East Africa calculated by 'Thornthwaite's method (Sansome, 26). The vertical line gives the average annual rainfall of the Serengeti area. 
humidity) and Olivier (24) and Thornthwaite (25) have developed methods of estimating the potential water-losses ("evapotranspiration ") from this cause. Using Thornthwaite's method, the values for this quantity have been calculated by H. W. Sansome (26) for different altitudes in East Africa, showing the effect of the fall in temperature at higher altitudes. The figures so calculated are given graphically as a smooth curve in Fig. 1. It will be apparent from this that potential evaporation only falls below the general average rainfall of $30 \pm 2$ inches per annum at altitudes exceeding 7,000 feet. Thus, it is only at levels appreciably above this that any considerable annual rainfall surplus can be expected to be available for the continuous recharge of ground water supplies and springs. According to data supplied by the East African Meteorological Department the evaporation as measured by a Piche evaporimeter is higher than that calculated by Thornthwaite's method.

Data based on calculations of this type must thus be regarded as approximate but they give a result which corresponds (sce Section 6) with an effective climatic change, because this altitude is that at which marked changes of vegetation begin in the Crater Highlands and in the Lamunyane hills and where the elements of the evergreen forest vegetation develop. The results so calculnted would no doubt be more striking if the scasonal effects could be compared because any surplus water must be available mainly in the wet season when evaporation is least. On the ground there is little or no evidence in the dry season (other than that derived from the vegetation) of the altitude at which the annunl rainfall is in excess of potential evaporation losses. Even in the dry season, however, the extensive Olomoti crater at 9,000-9,500 feet contains large swamps. Evidently there is some excess of rainfall at this altitude, even though the rainfall record for Nainokanoka (8,700 fect) nearby suggests a rather sub-niormal rainfall of only 28 inches annually.

These arguments are valuable because they suggest the elevation, say 7,000 feet and upwards, of hills which ean be regarded as capable of storing water. The maps show the areas above 7,000 fect which might thus be of importance. They are also useful because they emphasize the great importance of any methods of reducing water-losses by reducing evaporntion. Lowering the temperature of the evaporating surface is the most direct way of doing this, shade from clouds or from vegetation being the most potent medium. MInp 6 (Section 6) shows the approximate present limits of woodland in the district. 


\section{(ii) Permanent Water Supplies-Their Distribution and QUALITY}

The permanent water supplies in the Serengeti region reflect these differenees in the precipitation-evaporation ratios. Permanent water in any quantity, in the ordinary sense of the term, is only stored in the Highlands where there is an appreciable excess of rainfall $(P)$ over cvaporation (E), i.c. $P / E>1$. Over most of

TABLE 2

Water ANALYses (IN PARTS per MIILLION)

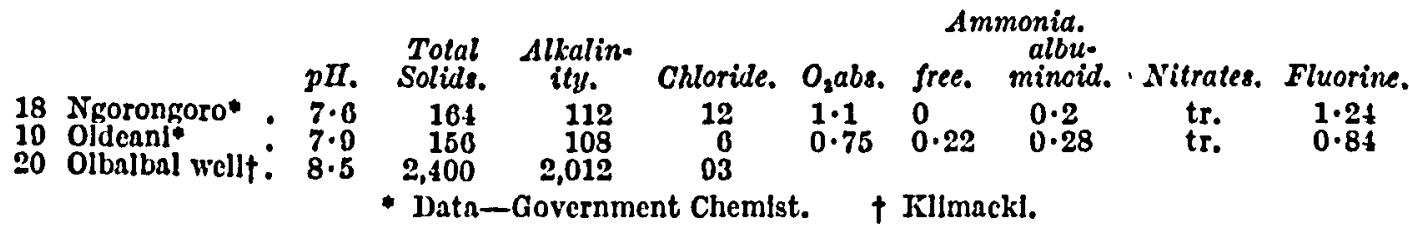

the area, particularly in the plains, the high evaporation rate results in the concentration of any stored water, so that limited supplies of saline or alkaline waters are the rule. Map 5 shows the distribution of permanent water mainly as observed at the end of the dry season in 1956, but with the addition of other

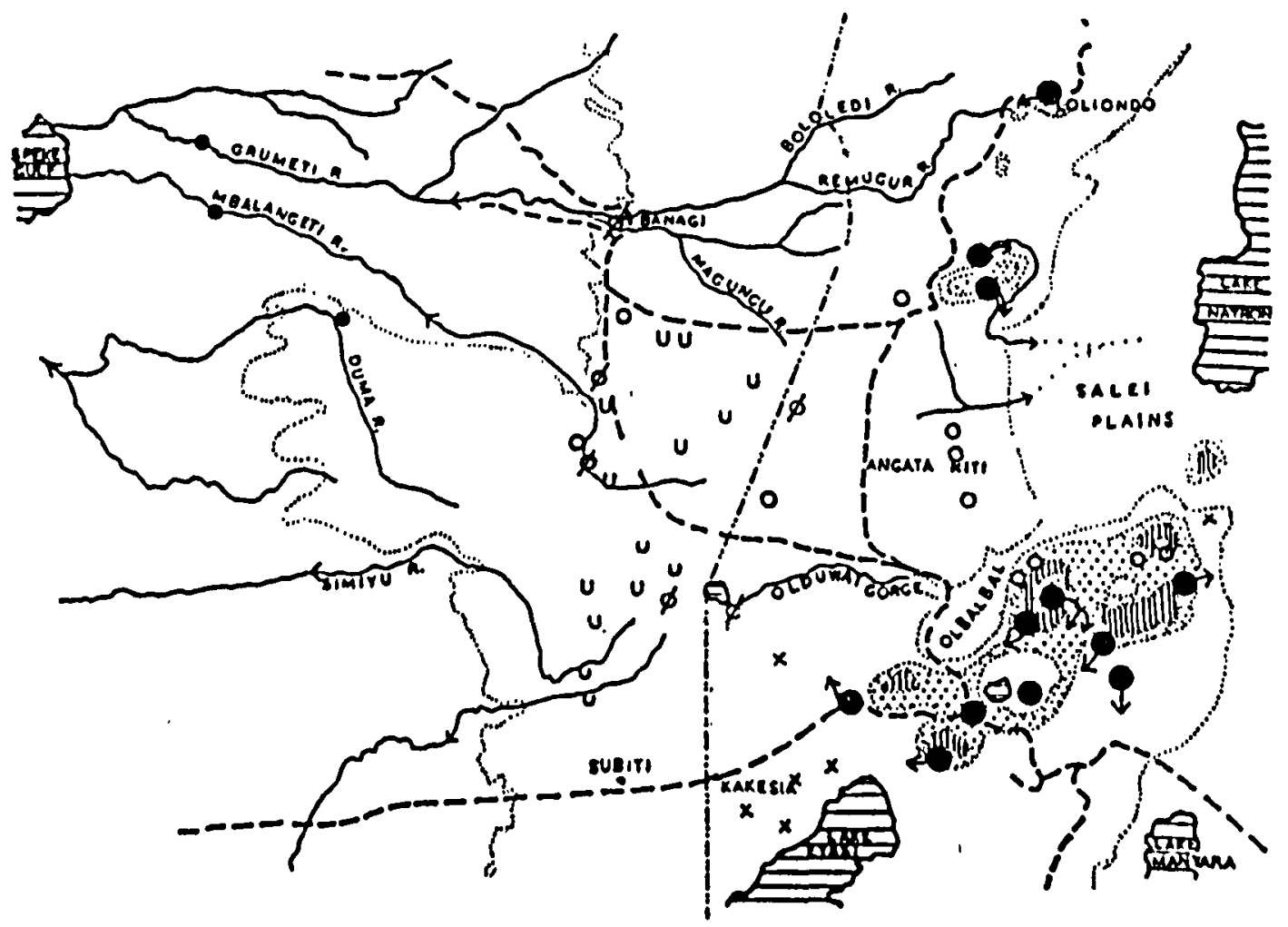

5. Distribution of permanent water in the Serengeti region. The large black dots are considerable sources; the small circles are minor sources extremely small when the circles are open, and saline when shown with a diagonal cross. Places marked ' $U$ ' are recorded wells and the crosses are recorded springs, not all visited. 
TABLE 3

Summany Table

Ngorongoro Crater.

$\begin{array}{ll}\text { Lake Magad } & \text { : } 01 \cdot 0 \\ \text { Swamp } & \cdot \mathbf{3 1 \cdot 5}\end{array}$

\section{Olduzuai. \\ L. Lagaja . $\quad 30 \cdot 0$

Sinoni $: 16.5$ Table 1 \\ Meira Mwei . : $\mathbf{2 3 \cdot 3}$ " 1}

\section{Plains.}

Oljoro laiser I . 42

Oljoro laiser II $\quad \mathbf{4 2}$

Upper Seronera , 8

Oltuka River $\quad$. 62

Oltuka IVell $\quad \mathbf{4 2}$

Loiyangalani River $\quad 0$
Rock Pools.

Moru . $\quad . \quad 1 \cdot 0$ Table 1

Eagle Kopje $\quad 1.3 \quad$ " 1

Upland Sources.

Endulen Streams $\cdot\left\{\begin{array}{l}2 \cdot 1 \\ 1 \cdot 8\end{array}\right.$

Oldeani $\quad . \quad 0.84$ Tnble 2

Mlto wa Mlbu . $\quad 0.8 \quad$ " 1

Ngorongoro Camp . 1.24 ", 2

Leitokitok Spring • $0.0 \quad$ (5)

Munge River $\quad 2 \cdot 1$ Tnble 1

Olalan River. $.1 \cdot 3 \quad$, 1

Western Rivers.

Magungu at Benagi $1 \cdot 0$ Table I Mbalangeti (Handa-

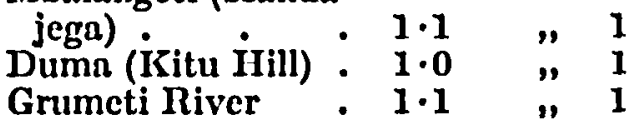

known springs or wells, derived either from the German map when confirmatory evidence was available, or from reliable recent sources of information, the National Parks sketch map, Dr. L. S. B. Leakey and the Water Department. The sources with a large supply at that time are distinguished by large circles. The correlation between their distribution and those of high altitudes and woodland is very clear (cf. maps 5 and 6 ) and demonstrates the importance of these features in water conservation. The absence of permanent water on the cleared upland areas is also very noticeable on visiting the area.

As to the quality of the water, analytical data are given in tables 1-4. In general, they give the total solids or conductivity as one measure of the total dissolved substances; the chloride

TABLE \&

Comparison of Fiuonine Content of Water Nontur and Soutil of Mlnuu

Northern Siles.

Engare Nanyuki-

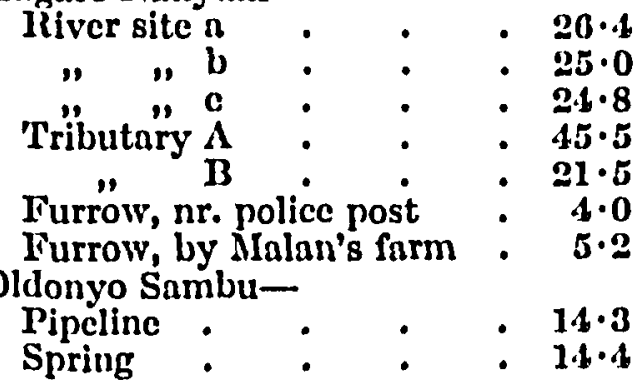

Southern Siles.

Arusha-Moshi Rond-

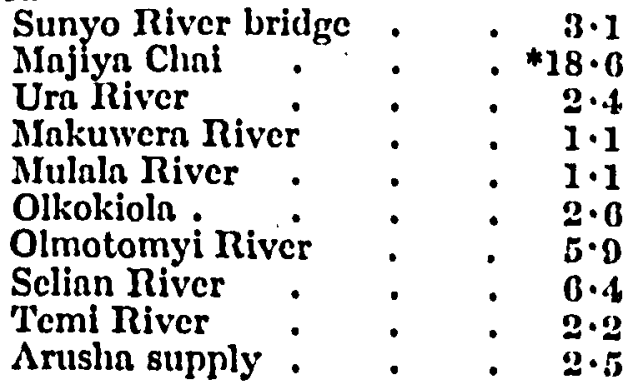

* Not used by human beings. 
serves as a measure of the salinity (common salt, sodium chloride), and the alkalinity ( $\mathrm{pH}$ values above $7 \cdot 3$ ) or carbonate contents show the relative amounts of soda (sodium carbonate). Fluoride may be toxic and is referred to separately. The analyses in Table 1 were from samples collected on this survey in early December, 1956, the others are from various sources.

The data for the central plains, Table 1, Nos. 7-14, and Table 2, 20, show that representative permanent waters from wells and water-holes are excessively saline and/or alkaline. Apart from No. 8 we did not actually see any of these waters being used by stock, game or Masai about the time when the samples were taken, although some of plains wells were apparently in use. No. 10 is of interest as being from such a well, though not accessible to animals and reserved by the Masai for human consumption. No. 9, not far away, may be similar water after exposure in water-holes along the River Oltuka, concentrated by evaporation and probably contaminated by the saline soils accumulated round the water-holes as well as by cattle.

The rivers are seasonal in the plains area and Nos. 11, 12 ; $7-9 ; 13,14$ of the analyses already discussed respectively represent the main sources of the Magungu, Mbalangeti and Olduwai rivers at the end of the dry season. At this time permanent water is only present in river-bed pools lower down in the Banagi region, where the rivers pass into the western bush country. This is used by game in limited amounts (annlyses 1 and 7). Lower down the rivers, though there may be saline pools, fresh water can be obtained by digging in the river-bed and this apparently represents the drainage from the surrounding hills on the surface of the underlying rock. There is permanent water of this type in the lower parts of the three main rivers as shown in samples Nos. 2, 3 and 4, Table 1. This is the water used by game in the dry scason grazing.

The rocky kopjes which stud the plains often have very small permanent water-holes or small patches of swamp plants like Typha (bulrush), water being held up in hollows in the granitoid rocks. 'There are two samples from water of this type, Nos. 5, 6, Table 1, No. 6 bcing the last remains of what used to be the running springs on the Moru Kopjes.

There are probably similar small water supplies among the western hills (as judged from the air) but no visible pools, waterholes or streams were seen at the end of the dry season (November, 1056).

The water supplies in the Crater Fighlands may be of good 
quality as far as taste and appearance are concerned. Water from volcanic rocks is always liable to contain excessive amounts of fluorides. These lead to disturbances in bone development, in particular to dental decay and mottling in human beings. Besides the voleanic rocks of the Crater Highlands, much of the plains area is also covered by volcanic ashes, either sedimentary or recently deposited, which presumably might affect the fluoride content of the water. Thus, it seemed necessary to determine how the fluoride content varied in representative water samples. The upper limit of fluoride for human beings is generally considered to be 3 p.p. million, and probably less is desirable for children. Cattle are more resistant and are said to tolerate up to 15 p.p. million. No doubt much depends on whether the animals are mature or not and also on the breed. To illustrate these effects Table 4 gives data from north and south of Meru-the Arusha waters from south of the mountain are found to be satisfactory except for that from the Majiya Chai, a polluted river which is not used. The waters sampled from north of the mountain come from a region where the human population show brown and deformed teeth, while cattle (including those of the Masai) show strong symptoms of fluorosis, including deformed jaws.

According to the Tanganyika Veterinary Department, cattle using from birth water containing more than 18 p.p. million of fluoride show these symptoms in varying degrees. Over 25 p.p. million abnormal bone growth occurs, resulting in lameness and in brittle bones which readily fracture. 'Tecth become very soft and rapidly wear down to the gums.

An examination of the tables shows that the representative waters from the plains and the Crater Highlands contain undoubtedly toxic amounts of fluoride. The waters suitable for human consumption are those from the granitoid rocks and those from springs and rivers with a high rate of flow in and around the Crater Highlands. The waters of the Munge River, Leitokitok Spring, Ngorongoro Camp supply and Olalan are all of good quality in this respect. Owing to scarcity of time, we were not able to sample the Engare Rongai River, but the sample from Mto wa Mlbu was taken as probably representative of the river water on the outer and enstern fnces of the highlands, as it agrees in general character with those from Oldeni and Endulen.

The small amounts of water available on the granitoid rocks make it unlikely that there is much scope for immediate development in the western hills. The plains waters nppear to become generally unsuitable for continued use. It thus appears that any 
development based on water supply should be around the Crater Highlands, both because there are waters of good quality there and also because the supplies are continuous. The importance of ensuring the continuance of these supplies by every possible means is emphasized again.

\section{(iii) Water Conservation}

It should be apparent from what has been said above that water conservation involves three main elements. These are, firstly, that all possible woodland or shade causing vegetation should be maintained and extended; secondly, that the catchment areas of the existing permanent springs should be maintained under woodland or a form of vegetation giving good shade and low temperatures at soil surface; thirdly, that all land above 8,000 fect should be regarded as water catchment and maintained primarily for that purpose.

In discussing this subject it should be remarked that the control of the catchment areas is vital to the future of the human population in the Crater Fighlands. The manner in which human settlement and woodland clearance is taking place on the collecting grounds of the main permanent waters is appalling to anyone interested in conservation and contrary to all the experience obtained in India and in other parts of the world with a similar climate. Almost every mountain seen in this survey and every woodland showed scrious fire damage, even excluding the extensive zones of firc-resistant grassland or mountain heath which may be ancient in origin. Especially scrious, perhaps, is the fire destruction around the headwaters of the Oljoro Nyukic and on the lower part of the Crater woodlands south of Oldeani, the gathering ground of the Olmbaserai. Settlement and cattle-treading have produced much clearance in the gathering grounds of the Engare Rongai and fire and grazing are causing scrious damnge on the south-west of Olomoti. The Ngorongoro Crater is being gradually denuded of its marginal woodlands by fire and so is the Embngai Crater. The outer rim of the latter is nearly cleared where forest existed quite recently. The desiecation of the permanent water here will no doubt follow. Lamunyane, the hill between Olalan and Arash, badly needs attention on account of its important water sources. The actual summit above a rolling plateau is used as dry season grazing and might no doubt remain as such if the woodlands are preserved and if overgrazing and soil crosion are avoided. 'The immediately important areas here are the fringing woodlands, mostly on steep slopes and now suffering severely from crosion 
due to random grazing and treading, as well as from marginal burning. Grazing on them should be stopped and cattle movements through them should be restricted to severely limited paths in the interests of water conservation. The above areas are important ones where immediate action is desirable. Many others were seen.

Places of this type are naturally attractive to native pasturalists or agriculturists for their occupation offers for some years the exploitation of soil fertility accumulated under woodland. The distribution of domestic animals around the highest peaks shows that this is what is happening generally in the Crater Highlands. The use of fire to control thie derived grasslands and to clear the woodlands is not only wasting this fertility, but is inexcusable in eatchment areas because it exposes the soil to increased evaporation as well as to the erosion which is liable to follow on the steeper slopes.

The objection that cleared ground if left will grow up to forest again through a dense scrub or thicket impenetrable to animals is based on a mistaken conception that the best use of all land is for agriculture, pastoral or arable. This is not the case in vital water conservation areas. The real objection to dense scrub in areas such as the Crater Highlands is that in a land where big game abounds, particularly elephants and buffalo, these may delay the redevelopment of woodland and maintain the scrub stage semi-permanently. It is not known how seriously this damages the water conservation value, which will, however, probably be above that found in most grasslands.

The whole question of the treatment on the upper hills and its bearing on the problem of water conservation is one of the most important in the Serengeti. It cannot be solved in this type of report but merits detailed examination and long-term experiment. In view of the widesprend existing damnge a policy of netive forest regeneration seems to be indicated, though it will obviously offer considerable difficulty. Provisionally, however, the rescrvation of all land over 8,000 feet for protection against fire and vegetation destruction secms imperative if water supplies are to be conserved. 


\section{Section 5}

\section{SOILS}

The geological outline of the Serengeti region as it bears on the present problems is fairly simple. The Crater Highlands are a rolling plateau with projecting peaks, all composed of Tertiary volcanic rocks which weather fairly rapidly. They are remarkable for the presence of a series of caldera, c.g. the craters of Ngorongoro, Embulbul and Olomoti, as well as for more direct signs of volcanic action. The only active volcano at present is the detached cone of Lengai, to the north-east, still at intervals discharging dust and ashes which fall on the castern plains.

The Serengeti plain reflects in every way the effects of this long-continued volcanic activity. The basic structure of the plains is an underlying complex of old and rather acid rocks, the basement complex, replaced towards the west by granites of the granitoid shield. 'These rocks are for the most part buried beneath great depths of volcanic ashes and limestones, in some places deposited under lacustrine conditions, some of which are exposed in section in the Olduwai Gorge. The characteristic surface deposit is often a silty material, pedologically immature, which, because of its originally sedimentary nature, tends to have a uniform particle size and to show a strong tendency towards close packing whenever subject to cattle-treading or to the beating effects of rain following exposure. The impenetrable surfaces formed in this way lead to surface run-off and to soil crosion. At the same time, the depth of the deposits means that with a strongly scasonal rainfall, water absorbed by the soil soon sinks out of reach and is largely unavailable to plants in the dry season. The continuous supplies of soil-water are thus found only where the underlying rocks are near the surface, in depressions in the sediments where the underlying peneplain of acid rock may be exposed, and near isolated tors of granitoid material, or inselbergs, projecting here and there on the plain. These with their strikingly different biota and water relations are one of the characteristic and most interesting features of the Serengeti proper.

'The other striking fenture is the difference between the castern and western halves of the plain, these differences being associated with the existence of sedimentary soils in the west and of the more dusty and mobile surface deposits of recent voleanic origin in the cast. 'The differences are not only the apparent physical textures of the two types of soil but also those associated with 
the continual addition to the surface in the eastern plains of fresh mineral material which, in view of its own chemical composition, is the equivalent of a manurial dressing. The effect can be illustrated in two ways. One is by the simple one of comparing $\mathrm{pH}$ value and the electrical conductivity in aqucous extracts of the soil; the other is by attempting to estimate the total reserves of important minerals in the two types of soil. Data on the aqueous extracts are given in Table 1. In this table, in effect,

\section{TABLE 1}

Comparison of Sunface Solzs fnom Two Transects across the Senengeti Platins ( $1: 5$ Soll SUspiensions)

Sample Conductivity

(a) Cynodon-Digitaria grasslands . Volcanic nsh-Enstern plain $\quad \vdots \quad \vdots \quad: \quad 14 \quad 7 \cdot 5 \quad 215$

(b) Transitional-just cast of Provincial Boundary $\begin{array}{rrr}13 & 8 \cdot 2 & 188 \\ & 8 \cdot 1 & 130\end{array}$

(c) Pennisctum-Themeda grasslands : • . $\begin{array}{llll}7 & \mathbf{7} \cdot \mathbf{0} & 105\end{array}$ Western plain $\cdot \quad \cdot \quad \cdot \quad \cdot \quad \begin{array}{llll}7 \cdot 0 & 5 & 60\end{array}$

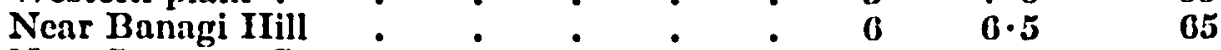

Near Scronera Camp $\quad \cdot \quad \cdot \quad \cdot \quad \cdot 15$ 0.6

high $\mathrm{pII}$ values and high conductivity indicate higher amounts of soluble material, some of which is available as plant food. Further analysis shows that the eastern soils contain considerably larger amounts of soluble material in general and particularly of sodium and calcium.

The more detailed gross ash analyses of the same soils in Table 2 shows similar features as well as indicating that the castern voleanic soils contain more potassium and magnesium

TABLE 2

Average Minemal Composition of Sunface Solls-Penchentage of DnY WhialtT

7 samples from castern plains, ca. $5,000 \mathrm{ft}$. .

6 samples from western plains nnd Moru, $c a$. $5,000 \mathrm{ft}$.

0 samples from Crater IIighlands, 8,000 to $0,500 \mathrm{ft}$.

\begin{tabular}{|c|c|c|c|c|c|c|}
\hline \multicolumn{6}{|c|}{ Ditr Whight } & \multirow{2}{*}{$\begin{array}{l}\text { Organic } \\
\text { matler. }\end{array}$} \\
\hline $\mathrm{Na}_{2} \mathrm{O}$ & $I_{2} O$ & $M I g O$ & CaO. & $\mathrm{Fe}_{2} \mathrm{O}_{3}$ & Silica. & \\
\hline $1 \cdot 5^{*}$ & $1 \cdot 5$ & $1 \cdot 0^{*}$ & $2 \cdot 8^{*}$ & $8 \cdot 0$ & $63 \cdot 4$ & $5 \cdot 0$ \\
\hline $0 \cdot 2$ & $1 \cdot 0$ & 0.5 & $1 \cdot 1$ & $8 \cdot 6$ & $73 \cdot 2$ & $5 \cdot 3$ \\
\hline $0 \cdot 5$ & $0 \cdot .6 *$ & $0 \cdot 3$ & $1 \cdot 4$ & $13 \cdot 1^{*}$ & $52 \cdot 1 *$ & $15 \cdot 4 *$ \\
\hline
\end{tabular}


than do the sedimentary soils of the west. The table also contrasts the soil characters of lowland soils with those of the higher parts of the Crater Highlands, as well as comparing the two types of soil just mentioned of the plains. It will be noted that the upland soils are poor in potash $\left(\mathrm{K}_{2} \mathrm{O}\right)$, one of the more important mineral requirements of plants. They contain more iron (as $\mathrm{Fe}_{2} \mathrm{O}_{3}$ ) and much more organic matter. Table 3 indicates also higher reserves of nitrogen.

The last feature of the plains soils which is worth comment is the effect on the properties of the surface soils of clearing away Acacia or Commiphora bush. Only two sites were examined between Olduwai and Lemuta: one where a well-established Acacia-Commiphora scrub had stabilized a dune system and given more or less complete vegetation cover of about forty or fifty years of age, and a second where old and well-established Acacia spirocarpa scrub was being destroyed by fire and by cutting. Apart from allowing soils to become exposed to erosion again, the main effect of this treatment is to destroy the capacity of the soil to oxidize organic matter. "This is shown mainly by the high carbon : nitrogen ratio. There is not much difference in the total organic matter even on shifting sand-dunes, but very low proportions of nitrogen indicate that this organic matter is probably practically undecomposed grass remnants blowing about along with the volcanic dust. This effect is redueed where there is a permanent vegetation cover.

It is noticcable in Table 3 that in each class of soil-the carbon : nitrogen varies with the nature of the vegetation. In the upland soils, the lower values are obtained where there is good shade, under trees $(10,17)$ or Eleusine (21). In the samples from the western plains and Moru $(22,23)$ the lower values also come from beneath trees or a tall grass cover (24). 'This difference is most marked in the castern plains, where there are very high values (33-35) where the vegetation cover is slight or nonexistent.

The soil samples taken for analysis in the tables given here are all from depths of about 9 inches and do not represent all the data which is, strictly speaking, adequate for discussing soil characters. It was, however, practically impossible to envisage a proper soil survey, which would involve digging of deep pits to get soil profiles, so that the only profiles to which reference is made are those which were cxposed by crosion or by human activity. There is no doubt, however, that a more complete soil survey would be of considerable advantage, especially perhaps in the western Serengeti. 
TABLE 3

SOIL DaTa

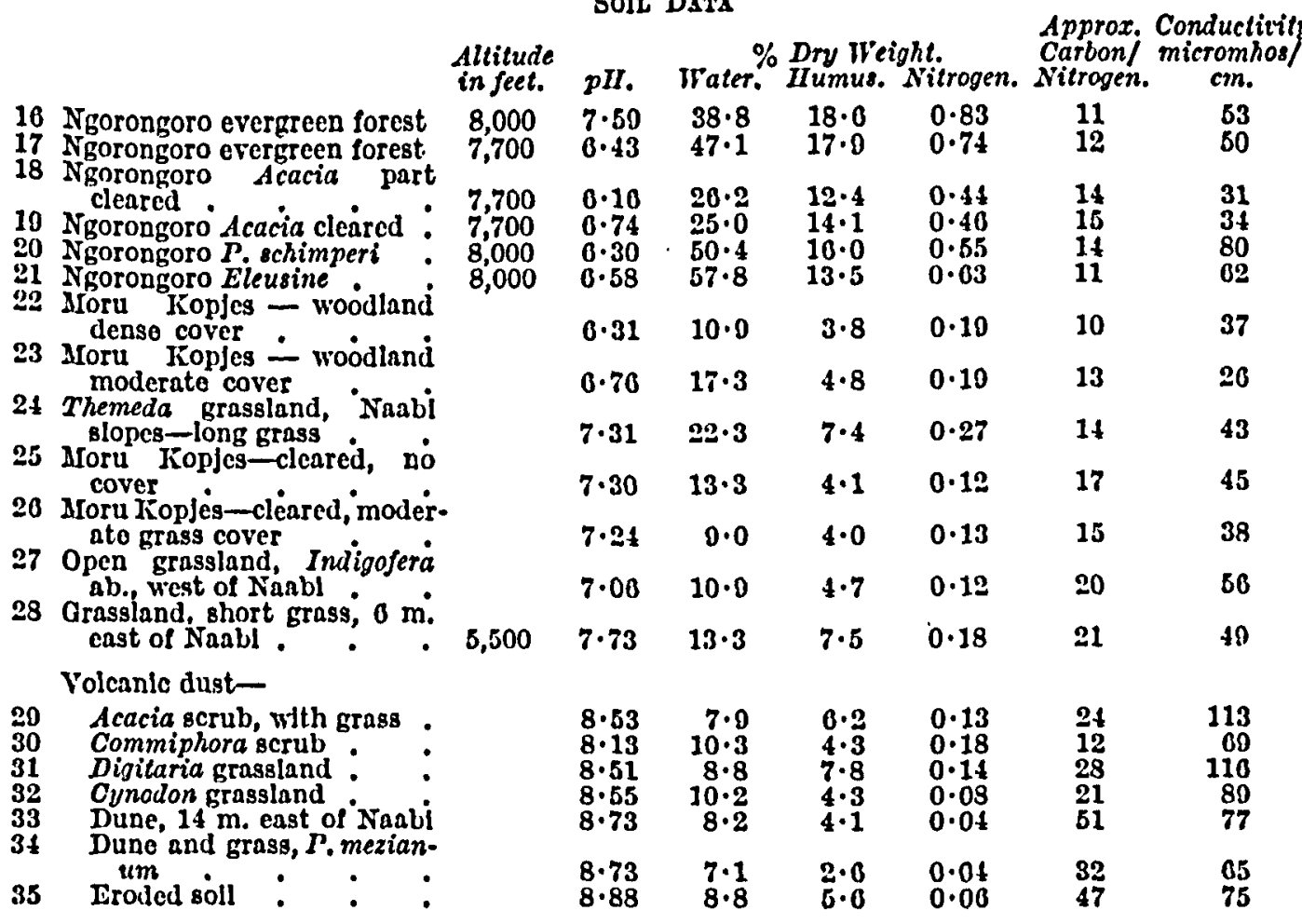

Among the western hills, or Mbalangeti region, the balance between the sedimentary material and rock exposures is reversed, the broad river valleys all seem to be filled with sedimentary material like that of the western plains, but the slopes on the valley sides show well-marked catenas starting from the rocky hills with reddish soils, derived either from granites or from the acid caps of Bukoba sandstone, passing into downwash slopes which quickly merge into the valley sediments. 'The transition is marked by changes in soil colour and in vegetation. The bush of the red and rocky hill slopes changes over to Acacia scrub with grasses on dark brown slopes below and then to dark and greyblack soils with impeded drainage in the valley bottom. In the latter there seem to be almost always calcareous coneretions below the surface at a depth of from 3-7 fect.

On the slopes of these hills and of the tors in the plains there is often striking evidence of erosion, though without detailed studies of soil profiles it is not possible to do more than describe the main features. The most usual sign is the presence of red downwash soils on the surface of soil which is dark brown and clearly of a different history. The red sandy downwash may be found at a distance of several hundred yards from the rocky slopes and the appearance of the whole strongly suggests recent 
crosion by surface water. More interesting signs of erosion are the presence of series of shallow steps in the slope, each perhaps 6-15 feet long, fairly horizontal, with a more rapid drop of 1 or 2 fect. Sometimes the step is bare, its surface covered with reddish sand and with grass tufts on the steeper slope of the margin, but quite often the difference in slope is shown by vegetation differences, the flat with Pennisetum mezianum and the slope with Themeda triandra. A good example of these erosion forms in an accessible place is to be seen on the north side of Naabi Hill. Often, if not always, the step phenomena appear to be associated with signs of woodland clearance, either by firc, or around bosses of granite by cutting and grazing.

These signs of erosion are only one of three things which suggest that the western hills are in an unstable condition and have possibly been exposed to recent erosion. In addition to these signs of soil heterogeneity on the slopes, there is also the skeletal and immature character of the soils on the hills themselves, and finally the immature character and disturbed nature of the vegetation cover. If this suggestion is the case, then there is room in the western hills for considerable biological development.

In the Crater Highlands the soils are for the most part red and kaolinoid in type. Very locally, on the margins of the Ngorongoro Crater and in similar situations, there are signs of laterite accumulation. Generally, however, the soils are stony and skeletal on the shoulders and decper and red in the hollows, usually in both cases with dark upper humus-rich layers and these are deeper along the secpage lines-cxamples are given in the tables. The high organic content of the surface layers is the characteristic feature of the soil samples taken and this agrees with the comments of Birch (27 and 28) on Kenya soils. In many places there is evidence of soil disturbance and at times of considerable sheet erosion in the past. Otherwise soils are acid and of rather high conductivity, the lowest being found in the Acacia zones. The high humus content means that nitrogen reserves are very considerable and as in soils from the lowlands, the carbon : nitrogen ratio becomes higher on sites which have been eleared of woodland, though this is apparently not the case under the grass Eleusine. 'The low soil potash content to which reference has already been made, may well be associated with other deficiencies.

The conditions under which the soils were collected did not allow of any detailed investigntion of the effects of overgrazing and of burning upon the soil conditions. It has been shown clsewhere in North America (19 and 20) that overgrazing pro- 
duces, by reducing the soil cover, continued desiccation of soil water and even that the amount of desiccation is proportional to the intensity of grazing. While the indications are that this is the case in the Serengeti, no detailed examination of the matter could be undertaken. Similarly, time did not permit of an examination of the effects of burning upon soil conditions. But the effect of burning is not only to increase the cvaporation rate by destroying protective shade, but also by destroying the organic matter which would normally fall on the surface of the soil to destroy the mulching effect of this material, which has very important effects on the rate at which water may be absorbed during rain. Similarly there is evidence both from the arid United States and from Britain that burning the vegetation cover tends in the long run to diminish the supply of available minerals in the soil. Under arid conditions this diminution is particularly likely to affect the potash content. There is room, therefore, for very considerable further investigation of soil conditions in different parts of the Screngeti in relation to problems of this nature. 


\section{Section 6}

\section{VEGETATION OF THE SERENGETI REGION}

The vegetation of the Serengeti area as a whole has its own particular interest, but is especially valuable in the present survey because it integrates the ecological conditions. It thus allows a rapid survey of these in a place where detailed information is almost non-existent. Thus, it is useful to know that each of the three main areas has its own characteristic group of plant communities, the Mbalangeti being mostly open bush, the Serengeti grassland and the Crater Highlands ranging from grassland to evergreen " mist forest".

The western hills show as their characteristic feature a "catena", or topographic series of soils and vegetation, which starts on the rocky hillsides with open Acacia-CommiphoraBalanites bush on red stony (skelctal) soils. On the downwash slopes below, Acacia spirocarpa usually forms a noticeable zone on soils which generally appear red-brown owing to their admixture of covering of granitic sand. As the slope diminishes the soils become darker brown in colour, more closely packed and alkaline, with $A$. drepanolobium as almost the only shrub. This is characteristically a plant able to withstand impeded drainage. Where the slope is negligible, black cotton soils with underlying calcareous concretions and Pennisetum mezianum grassland are usual, waterlogged and almost impassable when wet. These mbugas form corridors parallel to the rivers leading west, giving lines of movement along the valleys. A gallery forest along the river edge usually corresponds to a zone of improved drainage where the river cuts deep into the soil, although the higher humidity of the sites in the dry season is also no doubt an important factor.

The Acacia-Commiphora-Balanites bush is present over wide areas wherever the granitoid rocks approach the surface. Characteristic plants are Lannea stuhlmannii, Commiphora eminii, A. spirocarpa, Albizzia sericocephala, Rhus natalensis, Grevia and Balanites spp. It shows additional species in the damper northern areas around Olalaa and Loliondo, Erythrina burtii being especially prominent. In the west, at the lower end of the Grumeti, Mbalangeti and Duma Rivers, other additional species of Acacia, notably $A$. seyal var. fistula and $A$. malacocephala occur on black cotton soils, $A$. usambarensis on low ridges.

There is locally great variability both,in composition and in the degree of vegetation cover. The ground flora may be almost 
non-existent. The characteristics of the vegetation type wherever it was examined were those of a sub-climax or immature stage of vegetation. This would be consistent with the view that many types of bush are fire-climax types of vegetation.

The corridors of Pennisetum meziamum grassland along the lower reaches of the Grumeti and Mbalangeti rivers lead down to extensive alluvial plains around Lake Victoria. Here the grassland contains much Chloris gayana along with Bothriochloa pertusa, Eragrostis aspera, Cynodon dactylon and Cyperus species, while past oxbows neal the river contain Panicum meyerianum. It is this area which is the centre of the dry-season game concentrations. At the head of the river valleys the gallery forest is often replaced by a woodland of Acacia xanthophloea, the yellow-stemmed fever tree; at times the wild date-palm, Phoenix reclinata, is also very abundant.

The Serengeti plains proper carry mainly as vegetation two sorts of grassland. Over the western and central parts, grassland is dominant in which Pennisetum mezianum is probably the most abundant and widespread species. In the east Cynodon dactylon and Digitaria eriantha are usually most common. These differences are the response to a marked change in soil character which is observed going from west to east. The eastern part of the Serengeti is distinguished particularly by its dry and dusty soil. This is derived from volcanic ashes which are still being deposited at frequent intervals, six times in the last forty years from the cruptions of Oldoinyo Lengai, lying to windward, the prevalent winds being generally ensterly. Wind erosion is common, therefore, wherever the surface is disturbed by vehicular or animal traffic.

Between the Olduwai Gorge and Lemuta IIill there are extensive areas of dust-dunes, some still shifting with little or no vegetation, others stabilized under Commiphora subsessilifolia, Acacia nigrescens and Zymenia americana with occasional Acacia spirocarpa. The position of the most shifting dunes is indicated on the National Parks map, but the boundary between the two main types of soil is not well marked. West of the main dusty area there is a zone of yellowish, rather caked soil, otherwise resembling somewhat a locss. On one such site were Cynodon dactylon, Pennisctum mezianum, Aristida adscensionis, Sporobolus spp., Kalanchoe, Leonotus and an unnamed Lepidium. The volcanic ash soils themselves bear grasslands which contain in addition to Cynodon and Digitaria eriantha, C. plectosiachyım, Sporobolus spp., Eustachys paspaloides, Aristida species and a number of other plants which are accepted as indicators of dry 
conditions. In completely undisturbed localities, there might be about 80 per cent of the soil surface covered, but in most places the grassland consisted of isolated and projecting tufts of grass covering as little as 30 per cent of the whole area.

In the western Pennisetum grasslands the composition varies a good deal, however, in response to small differences in topography and soil, and especially to variations in the intensity of grazing. Widely distributed arc $P$. stramineum, Andropogon sp. aff. A. pratensis, Themeda triandra, Cynodon dactylon, and ephemeral species of Aristida, Eragrostis and Sporobolus. Of these the distribution of Themeda in abundance showed a strong correlation with the remains of Acacia scrub (or its recent presence) and with the red-brown soils found around the granjtoid bosses. Another clearly marked correlation could be seen wherever the long undulations of the plains surface could be followed in detail and particularly in the central region around the headwaters of the Magungu River. On the slight crests, Cynodon and Aristida spp. seemed to become more prominent, while the hollows between commonly contained instead Indigofera spinosa, Sporobolus festivus and Ileliotropium sp.

At considerable intervals, the faint undulations of the great plains are broken by shallow valleys, containing in the long dry scason only isolnted water-holes, but in the wet season the line of the rare rivers. Where the water is permanent it is strongly alkaline, or locally saline. In the western part of the Olduwai depression, Juncellus lacvigatus occupies the lines of water secpage, and around it, a sward-like zone of Sporobolus spicatus, Sporobolus homblei and local Diplachne jacgeri. Surrounding this, a drier zone of Chloris gayana and Justicia elliotii leads up to the marginal limestone with Acacia spirocarpa. Some of these lines of water-holes are still more alkaline, and Sporobolus robusta is abundant and Diplachne swards frequent, locally accompanied by Suacda monica (cast of Lagadi) and Atriplex sp. In these Cyperus spp. replace Juncellus lacvigatus. As almost all these drainage lines contain for much of the year the only available water, the adjacent slopes consistently show signs of overgrazing and soil erosion. As a result of the latter the limestones present below the surface (in some cases the concretionary lime layers in the soils) are almost always exposed and the vegetation scattered and ragged. At a greater distance from the exposures of concretionary material there are still usually pronounced signs of overgrazing, in which the vegetation. cover is evidently subnormal (sometimes as little as 30 to 40 per cent) and the plants occur in mosaic fashior and without much reference, for example, 
to possible topographic arrangements. Associated rather exclusively with these sites is IIarpachne schimperi while an alkaline soil indicator, Indigofera spinosa, is usually a prominent element in the vegetation mosaic, with Atriplex halamus var. granulata also present. Both Pennisetum mezianum and Themeda triandra have been observed persisting in such places, though the former is usually the more prominent element in the mosaic. The rooting level in these cases is just above the concretionary layer where the soil may reach a pH of 9 .

All over the plains area, but particularly in the south and west, are projecting tors or bosses of granitoid rock. They have usually characteristic woodland or scrub flora and faunafrequently they include small rock basins in which rainwater stands for weeks or even months. Around each was formerly a fringe of Acacia spirocarpa woodland and associated plants of which Themeda triandra and Sansevieria spp. are the most noticeable. The reddish soils are in marked contrast to the prevailing greys, dark browns and blacks of most of the plains. Characteristic of these bosses are species of Grewia, Euclea, Commiphora, Aloe, Sansevieria, Amanthis, Physalis and Typha, as well as Euphorbia candelabrum, Combretum guenzii, Papaya ugandensis, Ficus and Lannea spp., Chloris myriostachya, Microchloa indica and Cenchrus ciliaris. 'These, in many ways the most interesting part of the great plains, are gradually being destroyed by the Masai, who find them attractive places for their bomas and rapidly destroy the woody vegetation.

The Crater Highlands are a mass of Tertiary volcanic rocks forming an undulating plateau at about 8,000 feet. From these arise five peaks, between 10,000 and 13,000 fect high, of craterlike form. There are in addition two big depressions, the Embulbul Crater and the Ngorongoro Crater, the latter of which descends to a level about the same as that of the Serengeti plains. Two of the five craters are known to contrin neolithic sites and much of the area has probably been used by man for a very long time. The central plateau and the western slopes are much used by the Mrasa, who also go into the Ngorongoro Crater at frequent intervals. For these reasons it is probable that much modification of the original vegetation has taken place, so that what is now left is on the whole of secondary origin. There were probably formerly three types of vegetation. Forest and Acacia woodlands or scrub must formerly have been predominant; above them at 10,000 feet and higher there was mountain heatl in which bushy species were prominent. The bottom of the Ngorongoro and Embulbul craters probably contained lakes of 
varying size with swamps and as these receded the swamps gave way to swamp forest or to natural grasslands related to those on the moister parts of the Serengeti Plains. The Olomoti Crater contains considerable areas of Carex swamp (C. bequartii, C. lycurus) and is the only place where this vegetation type was seen.

The natural grasslands have certainly been widely extended by fire and grazing, thus much of the Acacia woodland and scrub has certainly disappeared. At the same time, fire in the mountain heaths has similarly depressed the upper limit of woodland, so that much of the mountain woodland is now represented either by Eleusine jaegeri grassland or by Artemisia afra heath or scrub, two widespread communities which are probably fire-induced and which are certainly fire-resistant. Though the present survey led to this conclusion, it may be of interest to comment that Gillman (17) had previously expressed a similar opinion. Edwards (13), however, does not.

Of the woodlands, the most interesting parts are the considerable areas of " mist forest" fringing the castern rim of the Ngorongoro Crater and almost the whole of the east-facing edge of the Crater Highlands (see map 6). Epiphytes are numerous and the trees are festooned with Usnea spp., as well as other lichens, mosses, ferns (mostly Asplenium) and orchids. Of the trecs, Bersama abyssinica, Pillarwood Cassipourea malosana, Láchnopylis platyphylla, Ekebergia rucppelliana, Teclea simplicifolia, Pittosporum viridiflorum are the most abundant species in the undamaged parts. Lianes festoon the tree clumps. There are in places, especially on the north-castern slopes of Oldeani Mountain, above 7,000 feet large areas of the Mountain Bamboo, Arundinaria alpina. Clearings in the forest are at first occupied by a dense tangle of Cynodon dactylon, sometimes with scattered clumps of Eleusine jaegeri. In places where development back to forcst is favourable, the clearings become occupied with a dense stand of Crotalaria imperialis followed by Vernonia auriculifera. At higher levels, 9,000-10,000 feet, the commonest trec is IIagenia anthelmintica with a scattering of Lachnopylis platyphylla and Pittosporum viridiflorum and stands of Lasiosiphon glaucus.

On most of the crater rims and the peaks of Oldeani, Olosirwa, Loolmalasin and Ela Nairobi, a form of shrubby moorland is present. There are various Ericacous shrubs such as Erica arborca, Philippia excelsa, $P$. jaegeri and Agauria salicifolia as well as Myrica meycri-johannis, a St. John's wort, Iypericum keniense, Protea lilimandscharica, Stoebe kilimandscharica, Arte- 
misia afra, Anthospermum usambarense, Psoralea foliosa, Smithia recurvifolia besides various shrubby and herbaceous species of Everlasting flowers of Helichrysum. Herb species of a temperate flora are present. Another interesting facies which is being ruthlessly cut is that dominated by the "pencil-cedar" (Juniperus procera). Small remnants of this remain in the Embagai and Oldeani craters, and on the castern face of the

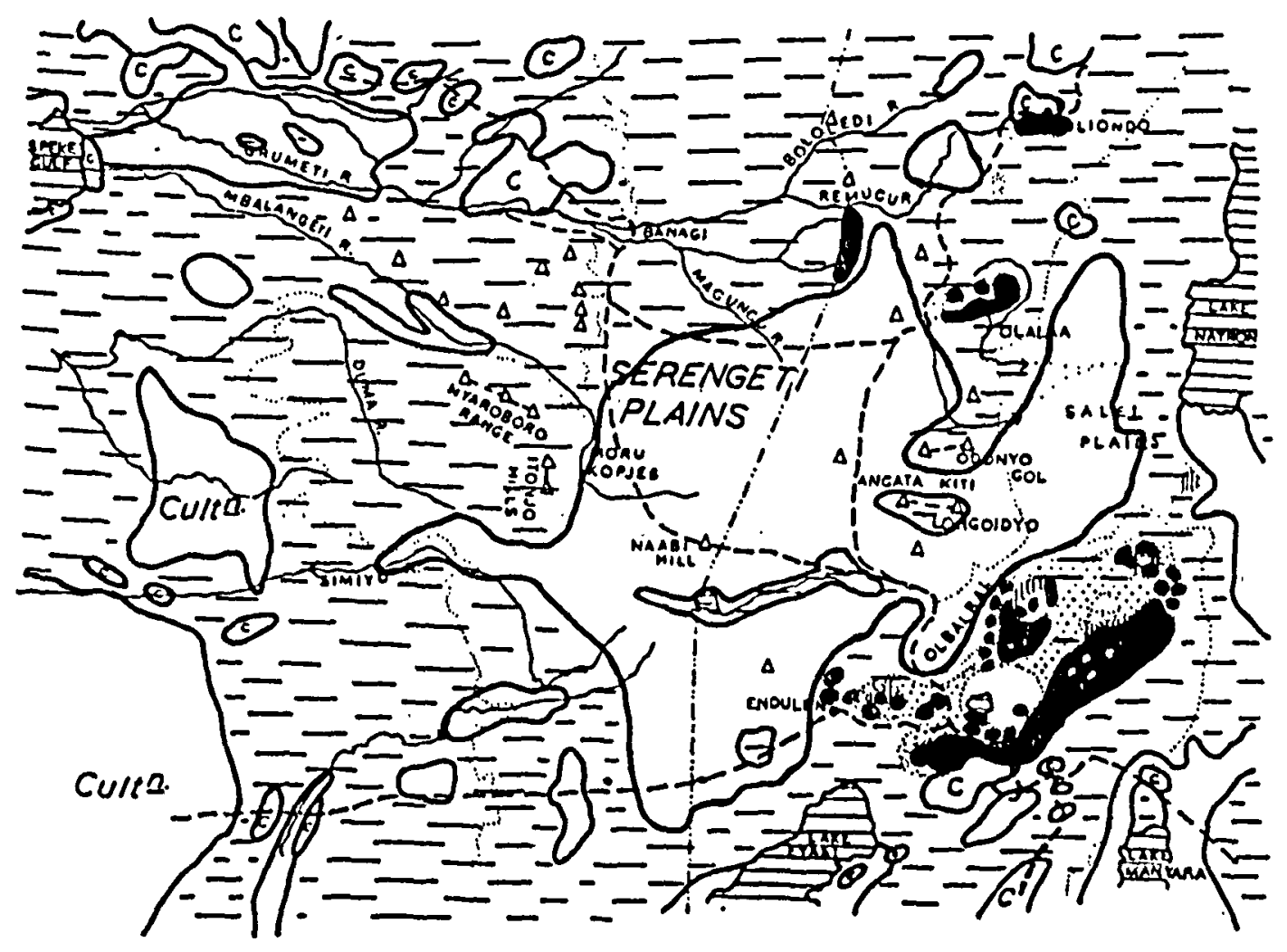

0. The vegetntion of the Serengeti region. Black = forest remnants, fairly continuous. 'The dashes show the distribution of grassland with trecs-bush in popular terminology. 'The open spaces are grassland without trees, cxecpt where marked witl $\mathbf{a} \cdot \mathbf{C}$ ' for cultivation.

highlands, but the stands on Lemagrut and on the western face of the highlands have practically gone. The "pencil-cedar" facies seems to be characteristic of the better-drained and drier habitats. On the gentler and wetter slopes, particularly on the north and west edges of the Ngorongoro Crater Acacia lahai formed quite extensive woodlands with continuous canopyalso now in danger of disappearing. Probably the best remaining fragment is on the southern slope of Oldeani but this was only seen from the air. The lower Acacia woodlands also show some 
variation with slope, altitude and exposure. A. xanthophloea, elsewhere characteristic of stream lines, occurs on gentle and presumably moister slopes at 6,000-7,000 feet. Somewhat better drainage gives $A$. spirocarpa woodland, but mainly below 6,000 feet. On seasonally waterlogged soils below $c a .7,000$ feet, $A$. drepanolobium becomes abundant. Speaking generally, then, the transition from the plains types of serub and grassland to the montane ones comes at about 7,000 feet.

It will simplify these descriptions if a few characteristic zonations are given in illustration. East of Loolmalasin and Olosirwa, where the vegetation is probably least disturbed, there is Artemisia afra as a dominant or a mixture of this species with Helichrysum schimperi and Stoebe lilimandscharica to about 9,500 feet; then it becomes much mixed (in the gullies) with IIagenia, gradually thickening with Cassipourea, Lachnopylis and Pittosporum, etc., and cither Crotalaria imperialis or Veronia auriculifera around openings. Below 6,000 feet the Acacia becomes more noticeable and, on the slopes flattening between 5,500 and 5,000 feet, the vegetation becomes grassland with Acacia. On the western side, however, there are now hardly any trees except isolated ones including Juniperus in and near gullies about 9,000 feet. Thus, the vegetation is upland moor (often much damaged by fire) and appearing as Artemisia bush down to 9,500 feet or so when it becomes largely Eleusine jaegeri grassland on the heavier soils down to about 6,500 feet or on the better drained soils Cynodon dactylon, Digitaria scalarum, Pennisctum clandestinum grassland. The bottom of the Embulbul Crater and its immediate surroundings appear to be very dry volcanic material, with a grassland in which Kikuyu grass, Pennisetum clandestinum, is dominant. Above this the principal grass is Pennisetum schimperi and extending to the north and west across broad levels much infested with mole-rats. In places these are so numerous (one hole per square yard) that the surface appears almost like that of a fallow ficld, with scattered tufts of grass and Salvia sp. nov.? aff. $S$. mudicaulis very frequent, giving not more than 50 per cent cover. Going on up the slopes of Olomoti, the Eleusine grassland reappears on the gentle slopes between 8,000 and 9,000 feet, to be replaced by a remnant strip of mist-forest (IIagenia and Lasiosiphon) along the northern ridge of the Olomoti Crater.

'Turning south across this crater reveals a large cxpanse of Eleusine jaegeri-Pennisetum schimperi grassland on the crater floor and Artemisia moor on its flanks, both much fire-influeneed and poor in species. Only on the northern rim, however, is there 
a continuous strip of mist-forest (IIagcnia mainly), though small isolated pockets occur on a hill in the crater and also here and there in gullies on the southern rim. The southerly slopes of Olomoti (below 10,000 feet), however, still contain considerable areas of woodland and derived bush, though even from a distance and from the air considerable fire damage can be seen. By about 8,000 feet the north-castern and south-western crater rims of Ngorongoro bears woodland composed mainly of Acacia lahai with some $A$. xiphocarpa.

The differences in vegetation thus indicated are no doubt partly due to the long occupation by human beings of the Embulbul Crater and its surroundings, and the resultant modification of the vegetation by fire and grazing. The crater contains a neolithic site and it is known that pre-Masai peoples were present in the area. It is known also that under the tension zone conditions so widely prevalent in this country, its marginal rainfall in particular, human influences are likely merely to accentuate vegetation differences which existed owing to differences in soil, aspect and so on. Forest has thus survived only where conditions were mostly strongly in its favour. In this connection it appears that the casterly faces lic exposed to the prevalent winds which bring rain from north-east and southeast and may thus be damper. This would not explain the differences in the Olomoti Crater and the contrasts between its western-northern and southern slopes. It thus seems possible that the dip of the rocks is also important. The evidence of the emerging springs on the south and west faces supports this suggestion and could account for the absence of woodland inside the southern rim of the crater. It will be obvious, however, on examining the maps that the presence of forest above the existing permanent springs and streams, and the absence of permanent water where forest no longer exists might well be capable of another explanation, that the destruction of forest had meant the desiccation of the water supplies. Even the casual visitor who went over this country would find much evidence strongly supporting this thesis, while a direct record of such a change exists in the Moru Kopjes.

From the point of view of this survey, the salient features of the vegetation are the widespread signs of disturbance. At least three of the widespread types of vegetation, much of the western bush, the Artemisia mountain heath and Elcusine grasslands, show evidence of being mainly fire-climax types and equally widespread are signs of fire damage on the existing woodland margins. 
Generally speaking the upland grasslands (above 7,000 feet) are derived from woodland of some sort and show much evidence of overgrazing, the combined effects of this and fire having produced very large areas of singularly unpalatable grass cover. Except where the grass has been recently burnt, there is little exposure of soil and on the whole not much soil erosion, though it may be severe on recently deforested slopes and on areas around water-points. The most striking damage is the destruction of vegetation around mole-rat colonies-as seen usually on nearly flat areas-but if it spread to the slopes it would lead to shect erosion. On the basis of the vegetation cover, the cloud cover and the distribution of mist and showers (during the dry season and beginning of the short rains) there has probably been considerable surface desiccation in the western parts of the Crater Highlands. On the plains also, there is much evidence of increasing desiccation, associated especially with damage to the vegetation cover by overgrazing.

The signs of this are very marked in areas used by the Masai, almost or quite non-existent in areas little used or unused by these pastoralists. An example of Masai effects in the Moru Kopjes area is considered in detail in Section 7, but similar effects were seen around almost any granite tor along the lines of Masai movement. The most widespread effects are no doubt associated with the destruction of grass-cover and exposure to evaporation and erosion of the surface soil. In the gently-sloping Serengeti plains the increased evaporation and soil compaction following the exposure of the soil are probably more important than crosion. Rain stands on and runs off the surface and does not sink into the soil. 'The effects of loss of vegetation cover alone are enhanced by those of fire which by destroying the remaining grass litter probably reduces the permeability of the soil to rain (cf. Percira, 15). The absence of overgrazing effects in arcas with large game concentrations is a matter of great interest and worthy of detailed study. It appears to be associated partly with the widespread and continued steady movement of the animals from one pasture to another. But no doubt the time of grazing after rain is also important.

$\Lambda$ more detailed study of the plains grasslands than was possible when the plants were dried up would be valuable. There was much evidence of the climination of the more palatable species in the heavily grazed areas and a general tendency in those of the less favournble habitats to extend (c.g. P. mezianum, Indigofera, etc.). A study of stocking densities would also be useful. It seems clear that these grasslands cannot be expected 
to stand the continued occupation which would result from permanent water-holes and that they are degenerating to poor and semi-desert types under existing Masai stocking intensities. There is thus no reasonable chance of them supporting both Masai stock and game concentrations. 


\section{Section 7}

\section{MORU KOPJES AND NGORONGORO}

The two areas of greatest interest from the point of view of suggested future developments are the Moru Kopjes and the Crater Highlands, particularly the Ngorongoro Crater, and a description of the pertinent features of each is therefore useful.

The Moru Kopjes are granitoid bosses projecting from the western margin of the plain. They are not greatly dissimilar from the other granite bosses scattered over the plains except that being grouped they form an important collecting ground for water-perhaps the most important catchment at the head of the Mbalangeti River. The granite bosses themselves are still usually wooded (though suffering much from reckless cutting of timber) and until recently the intervening areas of deep soil were also woodland, or at least grassland with numerous trees. There was, until recently, permanent water-at least two running springs (three witnesses, cf. also File 78, Game Department, 1947) and some which, on the evidence of marsh plants (rapidly disappearing), must have been nearly permanent. Only one spring contained water in December, 1056, and this was now no longer flowing but had sunk to a small pool deep in the rock (analysis in Section 4, Table 1, sample 6). The surroundings of this spring consist of a collecting area of about 300 yards by 400 yards between three rocky bosses. This was formerly woodland and it is known (and therc are abundant signs) that it has been recently cleared (within the last few years) by cutting and fire. The soil in the remaining fragments of woodland is a loose mould with high water-retaining and water-absorbing capacity. In the cleared areas the soil surface has become very hard, the soil has a close-packed texture, is practically impermeable to water, and has a low water-retaining capacity. Much bare carth is exposed and there are already numerous signs of erosion. Further soil data are given in Section 5 .

There appears to be no doubt that pronounced desiccation of this locality has taken place as a result of clearing woodland and burning. There were two Masai bomas in the immediate vicinity, and the observed changes are (probably justly) attributed to Masai. It is stated by a former Game Ranger (Mr. D. IK. Thomas) that these springs were in dry periods fenced to deny them to game.

The description of this single locality is typical of what is 
happening widely in the Moru area. The extent to which it has taken place can be gauged not only by the numerous signs of the former extent of woodland (see Section 6) but also by the distribution of ant-hill sites-now no longer active-which have been considered to represent areas in which ground-water is no longer within easy reach of the surface. The occupation of this region by Masai, whatever its nature, is in effect permanent at levels varying from 5,000 to 9,000 head of cattle and a smaller number of sheep and goats (Pullon, "Data on livestock populations, Masailand"). Permanent saline water-holes exist on the Oltuka River (samples 9 and 10) and near them a well used for human consumption. There are also well-maintained bomas to which a return is made at intervals. Within a mile of these water-holes the general condition of the soil and vegetation is extremely poor-this being one of the four most strikingly impoverished areas seen in the Serengeti Plains.

The Moru Kopjes area seems to be a vital part of the western unit of the National Park. It is certainly essential to the preservation of the plain's game and should not be alienated from this purpose. All observers are agreed that this is normally a significant concentration area in both eastward and westward seasonal movements, as indeed it was in 1956. At least two of the larger wildebeest populations are known to calf there, including the main western group. Later the animals become more widely distributed over the plains during the wet season, before reconcentrating around Moru prior to the movement west.

The Moru Kopjes are also the main part of the gatheringground of the Mbalangeti River, and as such they must be regarded as unsuitable for exploitation. Ecologically they are part of a tension zone- $\mathrm{a}$ borderland between woodland and grassland-and as such would be expected to fall rapidly to a low level of production of water and of potential fodder if exploited. Indeed, scrious damage has already been done to this area as has already been indicated and on the evidence it appears to be unlikely that they can scrve as a main concentration area for various types of game and also withstand more or less permanent occupation by Masai pastoralists. Freedom from firc and from continuous grazing is required at least for a time in order to enable regeneration of the damaged woodlands and reconstitution of the soil surface. No doubt this could be accomplished by extending southwards the stock boundary limiting the westward movement of Masai until regeneration had taken plince. 


\section{Ngonongoro and tile Crater Higiriands}

The second area in which the problems of conservation are especially serious is the Ngorongoro area. If the Crater is to remain as an attraction to tourists and its camp is to be a financial asset to the National Parks, presence of large numbers of plains game as well as of large forest animals is essential. For the latter the maintenance of adequate forest reserves for water conservation would suffice also for the conservation of the large forest animals and no further immediate steps are necessary. There have, however, been very large changes in the forest cover in the Crater Highlands since the first map, that of Jaeger in 1913, was made. Even the comparison between the present distribution and the map given by Gillman in 1949 shows yery big differences. The principal agency is evidently fire and the Crater rim at Ngorongoro, which naturally should mostly be bush or forest covered, shows how severely fire has limited the present distribution of trees. As an illustration of the importance of this problem it may be said that during my first visit to the Crater six fires were observed on the surrounding uplands; two of these which burned all night were in forest. Judging by the area of fire-damaged country which was seen on flying over the Crater Highlands, this condition is quite general. Very striking cxamples of fire-controlled distributions of vegetation are to be seen along the road from the camp to the west, especially on the north side of Oldeani. The north side of Lemagrut had been burnt from head to foot at the time of the survey. The second problem which seems to be arising in the vicinity of the camp as the result of the increase in the population, camp officials, visitors, Masai and also those inhabitants around the District Officer's camp, must be the provision of fuel and some thought needs to be given to the provision of suitable rapidly growing trees for this purpose. The present appearance of the woodlands on either side of the road and also along the road going to Nainokanoka shows that hardly any of the original forest remains there. It secms also that sooner or later some thought should be given to the proper balance between large animals and trees if the natural habitat as a whole is going to be maintained.

As far as the plains animals are concerned, mainly wildebeest and zebra, the numbers present in the crater and its vicinity at present seem generally to be adequate for the purpose of interesting tourists. In order to maintain them at this level it scems necessary to maintain the present paths of seasonal game movements, which are mainly over the west and north-west rim 
of the crater, down MIalanja and into the Olbalbal. If the crater is to be maintained as a show-place for plains animals, then the corridor along this line will be necessary for their movements. It is unfortunate from this respect that there are numcrous signs of increased Masai activity and apparently also of population along this line. The establishment of the District Officer's station and of a cattle market nearby is also unfortunate as possibly tending to increase Masai occupation of the area. During the time of my visit, Masai and their cattle, seen on the floor of the crater, seemed to be most often in the vicinity of the camp. This is natural enough as it is the side on which their settlements lie but it is again unfortunate from the tourist's point of view. It would be worth considering, if they are to use the crater floor, if they should not be allotted mainly to the northern part of the crater.

There seem to be only three ways in which presence of plains game in the crater can be maintained. One is as suggested, by maintaining a corridor through Malanja into the crater, and also by limiting the numbers of Masai grazing in the crater. It might be possible to treat the crater and the western corridor as a reserved area in which both the National Park Camp and the Masai had grazing rights, for which payment should be made on the basis possibly of 10,000 head for the camp and possibly a similar number of Masai cattle. The actual numbers could be provisional and could be revised as experience directed. Any money derived from these levies could then go to grassland development in the northern part of the Crater Highlands. The alternatives seem to be either to exclude Masai and their cattle entirely from the corridor and the crater, or alternatively, to allow the present distribution of the population to develop and to exclude Masai from the crater itself. It is about 160 square miles in area, and has a great variety of grassland and habitat. Hence, it might be possible to maintain or build up large herds of zebra, wildebeest and gazelle in the crater without allowing movement to and from the outside. This is likely to be the only possibility of maintaining a tourist attraction if the present increase in Masai activities across the western exit is allowed to continue.

The White Paper proposals imply that Masai are to be' excluded from the Ngorongoro Crater on the understanding that the Moru area is developed for them. It appears on the present evidence that the Moru area will not stand continued occupation, its present remaining value being that associated with the fertility resulting from primary exploitation. Morcover, the 
Moru is undoubtedly nodal to the game movements as well as a main breeding ground and it must receive very heavy use during the wet seasons from game concentrations. It will be impossible to envisage the present cological unit existing unimpaired as a game reserve without it. On these grounds I think that if only one of these two places can be reserved for game, it should be the Moru area, recognizing that this will do great, if not irreparable damage to the National Park interest at Ngorongoro Camp. 
Section 8

\section{NATIONAL PARK ORGANIZATION}

Some reference is necessary to the problems of the organization of the National Park in relation to its functions. These references are not to be taken as in any way critical of an existing organization which is not yet through its tecthing troubles. It may, however, be useful to record certain impressions of problems existing under the present arrangement.

One of these is the question of terminology. The existing definition of a National Park with no human occupants cannot be applied to a large part of the Serengeti and no doubt it is this which has prompted the White Paper alteration of boundaries (cf. (1) and Section 10).

Another feature of park organization which has created difficulty in Tanganyika is the status of the park officers which arises from the policy of putting the National Park under trustees. This had the obvious, and in many ways desirable, aim of making the organization independent, but it has in fact led to difficulty in the field administration of a body which is constantly coming into contact with human affairs and with problems of land-use. Under the present arrangement field officers may lack the advantages and authority which would derive from representing a branch of government. There is also apparently at least some justification for the view that at times the Masai have tried to play off National Park oflicials against district administration and vice versa.

The functions of a National Park organization as it is conceived in Tanganyika appear to be, firstly the provision of amenities which will serve to attract tourists, and secondly the preservation of the game and the prevention of poaching. The present limited staff in Tanganyika is necessarily preoccupied mainly with the immediate problems which arise from these two aspects of the case. Little or no time is available for the study of the game animals and their ecology, or for knowledge of the wider aspects of reserve management. These difficulties are increased when Masai are present and when any measure of control of their activities is necessary. However, the immediate problems of game preservation in such an area are only a small part of the wider ones of conservation. While the game is the focus of popular attention, its maintenance in suitable quantity can only be achieved in a highly varied area such as the Serengeti by a complete and intelligent system of land-use and nature 
conservation. In particular, it will be appreciated that the presence of numbers of game in a particular place is not necessarily limited by the conditions there, but may well depend on factors operating many miles away, where the animals breed, or spend a significant and important part of their life. It seems clear that the whole of the National Park must be planned and maintained as an ecological unit and that the staff must be sufficiently numerous and able enough to acquire the knowledge both to plan development of such a unit and to maintain it when planned.

On the basis of these considerations it appears that some thought could profitably be given to the question of the staff structure in National Parks and also the interlocking of the existing organization with that of administration. 


\section{Section 9}

\section{DEVELOPMENT}

The problems of the Serengeti National Park as at present delimited are mainly those of rival forms of land-use in a country which, because of the severe physical limitations, is not suitable for dual-purpose developments of the types which were originally contemplated. In considering possible developments, therefore, it is necessary to be clear first as to what are the primary objectives desired and then to see how far they can be realized within the existing physical limitations.

The unique and remarkable features of the area are the variety and abundance of plains game and of the varied habitats in which they exist. There are the strongest possible grounds, both scientific and amenity, for the conservation of these features as part of the African heritage. Both centre mainly around the Moru area and it seems that this should be the natural centre of any attempt to develop permanent game conservation. The immediate practical difficultics are small and the discussion of desirable developments may be left until a later stage.

In considering the possibilities for human and pastoral development, it is necessary to recognize that the present concentration of population will make it most economical to develop the region around the Crater Highlands as the main centre of human activity. The only considerable supplies of permanent water are in the same locality and the present distribution of cloud and shade shows significantly higher probability of rain, and therefore better water potentialities, just west of the higher summits of the Crater Highlands. Furthermorc, soil data show that the mineral character of soils in the eastern plains offers greater possibilities for development than do those of the west. This is borne out by the more palatable nature of the plants which make up the grasslands. All the possibilities thus agree in pointing to the greater potentialities of the castern part of the Serengeti plains.

Any real development in this area must depend on the use of water to the best advantage and on the success with which it is possible to strike a balance between the provision of water and of adequate grazing.

For example, there is little doubt that at present many parts of the Crater Hlighlands, especially those near permanent water, are over-grazed, while it is often the case that the plains area could stand heavier grazing, though it must not be assumed that 
the plains grassland could stand permanent occupation. The grazing in the plains is, in fact, strongly seasonal and thus often it is doubtful whether the provision of permanent water near it would be worth while. Even on the evidence of the existing water-holes (sce Sections 4, 5 and 6) soil erosion and the rapid degeneration of the vegetation (e.g. to salt bush) would certainly follow permanent occupation. There are thus strong arguments for using a form of temporary rainwater storage (e.g. haffirs) to make full use of the seasonal vegetation. Any such provision should be as widely spaced as is possible to minimize trampling and crosion effects.

The possibility of increasing the available water supply should also be considered. It must be assumed that everything possible will be done to conserve the existing water catchment areas, especially those over 8,000 feet and all the remaining woodlands. Real development should consist of attempts to increase the available water. The most worthwhile method of accomplishing this would be to carry out experimental afforestation or some form of natural surface shading of some of the cleared arcas, especially those serving a depleted spring or a seasonal stream. A cursory examination of the Oldonyo Gol suggests that it would be profitable to try afforestation there so as' to explore the possibility of extending the permanent water. Failing this the scasonal water in that area should be dammed in order to extend the grazing period. The Angata-Kiti here appears to be capable of withstanding much heavier grazing.

Where permanent water is piped to provide a wider distribution it is very important that a large number of service points should be provided (with automatic stopeocks or an arrangement for periodic supply) so as to spread out the trampling and erosion effects as well as local over-grazing. One of the worst examples of soil crosion in the whole district is to be seen around the end supply-point of the Nainokanoka pipeline at Naguro.

Permanent water supply, wherever it occurs or has been provided, is at present constantly associnted with over-grazing effects. 'Thus, the second and probably the most immediately effective service which could be rendered to the Masai would be the development of suitable methods of grassland improvement and of range management in the arcas concerned. . These are likely to be of two main types : those suitable for the plains grasslands and those necessary for the high-level areas. In the plains around the Crater Highlands where the soil surface is often loose volcanic dust, disturbed by everything that passes, even wind, it would be desirable to find methods of stabilizing it. 
The establishment of a continuous cover of a mat-forming or rhizomatose grasses would be of great value here, and also the provision of a solid road surface from Olduwai Gorge to Soitayai as almost every vehicle that passes disturbs a new route. Better still would be the complete diversion of the Ngorongoro-Loliondo road.

In the uplands, the more obvious main problems are the prevention of trampling and erosion around water supply-points and the redevelopment of grassland types valuable as pasture. The present grasslands are often merely fire-resistant or unpalatable remnants (cf. Gillman, 17).

The whole question of grassland and range management should, however, be the subject of proper investigation, as it is obviously unlikely that a visitor can do more than see the need for proper treatment and suggest the type of problem involved.

One of the main problems in the development of the Crater Highlands is thus the treatment of the very large arca of Eleusine grassland. Eleusine jaegeri is apparently worthless as fodder and it occurs in large tufts, as much as 3 feet in height and in diameter, which almost completely cover the ground, shading it so that there is little or no vegetation between the tufts. It is a fire-resistant species and covers ground which was undoubtedly formerly woodland between 7,500 and 9,500 feet, probably as a result of long-continued burning and grazing.

It may well have one virtue, for it shades the ground very completely, reducing the soil temperature and thus probably reducing the evaporation rate so that water conservation may not be greatly different from that under the original woodland. It is this feature which necessitates some care in its treatment. The Masai method of trying to use it is simply to burn frequently and to graze sheep and goats on the vegctation which may appear between the tufts after burning. This is a poor method as it eliminates most other plants before Eleusine and frequent fires are indeed probably responsible for much of the dominance of this grass. The more correct method would no doubt be to attempt to replace the Eleusine grassland by a form of pasturable woodland. The trees could cast as much shade as the present grass and this would climinate the Eleusine (as in the original woodlands) permitting the. development of a more palatable grass cover on the ground. The woodland could thus serve for water conservation, grazing and wood for fuel or building. Suitable quick-growing trees could no doubt be found, as several trees of this type have already been satisfactorily planted at Nainokanoka. The establishment of pasturable woodlands might 
be extended profitably to lower slopes than those under Eleusine wherever reconstitution of the grassland is required. The woodlands could no doubt pass through cycles of regeneration and pasture-use, much as in the Indian protection forests.

Any methods of grassland control or the provision of permanent water will raise another point: the probable need for the development of some form of replacement trcatment on the pastures nearby. If the Masai only maintain their present rate of sale, slightly above 5 per cent of the total stock (Section 3), the whole weight of material (nitrogen and mineral) required by that stock will have been taken from the area in less than twenty years. It is possible that such a rate of mineral removal may not be a serious drain on new soils of volcanic origin, but even if this is the case, it scems improbable that the rate of nitrogen fixation will be maintained at such a high rate. The grasslands usually contain few or no leguminous species, for example, and the nitrogen reserves are extremely small in the plains grassland soils. The upland grasslands in contrast are more likely to require some mineral manurial treatment.

If the western area, the plains and Mbalangeti, is to be the main centre of game conservation, its development will be at least as important as that of the Crater Highlands and their vicinity. From the point of view of tourist traffic, the first necessity is an all-weather road across the plains. This will enable them to be visited during the wet season when the concentration of game is at its height and tourist attractions are greatest. A road with a hard surface is necessary through the Olbalbal and north of the Olduwai in order to reduce the excessive erosion which is now taking place in that area.

If further tourist traffic through the plains is to be developed, camping-ground facilities at Naabi would no doubt be necessary, especially to avoid wood-cutting and fire damage. The game facilitics around Naabi would become of the first importance as well as those in the approaches to Seronera. These are not compatible with the present spread of Masai graziers in these arcas.

The important developments, however, would be those conecrned with game conservation, such as the determination of the stock numbers representing different species and the balances between them, their movements and ecological requirements. It will probably be necessary to limit the numbers of some species in the interests of others and of the vegetation and to limit the lines of movement in order to keep animals in the park. This will no doubt require the development of water, grazing and 
cover in suitable places. The MIoru Kopjes area in particular will need much attention. The planning should consider the probable needs in drought years.

In general, development should not be based only on the amenity interest and tourist traffic, but on the assumption that game preservation is a form of land-use. It can be argued that suitably-managed herds of game animals, such as wildebeest, gazelle, impala, ctc., will yield as much or nearly as much protein or meat as cattle. Suitable control of the balance of populations is likely to require number control of many elements in the fauna. If this is so in the Serengeti, game preservationthe prevention of poaching-should go hand in hand with suitable cropping undertaken by hunters under National Park control and organized on a commercial basis. Much successful animal conservation in other parts of the world has been based on number control of this sort.

The preservation of the plains game is the main object of this reserve area and this must therefore be given priority of interest, nevertheless conservation measures should not lose sight of the high scientific interest of the area as a whole, its fauna and flora, and of the importance of conserving and redeveloping the habitats. In the grasslands, wildebeest have been observed during the survey to prefer different types of pasture under different environmental conditions and this suggests that valuable results, both for scientific conservation and economic purposes, might be obtained from proper grassland grazing studies. The extremely interesting granite tors or inselbergs on the plains would repay much redevelopment, not only because of their scientific interest but also as a means of increasing water potential and cover in dry surroundings. Lastly, the impression is recorded earlier that the bush and soils of the rocky hills in the western Serengeti represent immature plant and soil covers. This suggests that it would be profitable to attempt the development of these elements. Immunity from fire would no doubt do much, but this would only yield long-term developments. The possibility of active planting or afforestation of different types of plants is worth considerntion; the point would be that a considerable development of water resources as well as additional shelter for the larger game animals could possibly result.

There is, however, the larger point in a country like Tanganyika, where so great an area is covered by forms of bush, scientific study of this type of country and of its conscrvation and experimental development would no doubt be likely to yield results of great value in other fields, as well as being the necessary 
basis on which long-term game and habitat conservation must be planned.

It is recommended that a unit be set up for research in the general field of game and habitat conservation. The Serengeti area would be a very suitable area for work in this field and the unit should be attached to the National Park, even if more suitably administered by the Game Department or the Member for Natural Resources. 


\section{Section 10}

\section{RESERVED AREAS AND BOUNDARIES}

If the principles laid down in the first section of this report are accepted, the Serengeti area will need to be divided into three main groups of sites : the first a game reserve, the second a Masai settlement area and the third a forest and water conservation area. In describing boundaries for these areas there will be a need to give attention on the ground to the suitable features which can be readily identified. The following description, therefore, deals mainly with the particular points involved in siting boundaries in certain places.

In view of the character of the observed movements and of known breeding places of plains game it seems that the minimum area likely to give permanently viable reserve would extend from Banagi down the Grumeti river to Lake Victoria; thence it would go approximately from the mouth of the Mbalangeti via Masewa to Nyawa Hill and the Simba Kopjes, including both sides of the River Duma. From the Simba Kopjes south-east and along the general line of the Simuyu river it would go to the present park boundary, following this to the provincial boundary and thence to Lake Lagaja. East of this lake the Olduwai Gorge is an obvious and suitable boundary for some distance; a natural eastern boundary, excluding for the present the question of access to the Ngorongoro, would seem to be the line Naibardad, Lemuta, Grumechen. Existing park boundaries would be followed along the northern edge by the Orangi and Grumeti rivers. I recommend that the area within this boundary should be classed as National Park.

The final boundaries must recognize that the relevant information about game movements is at present unsatisfactory in at least three places, and suggestions as to the boundaries in these areas must be regarded as provisional and open to revision. There are reports of considerable game movements to the south of Lagaja Lake, but it appears that these are mainly covered by the existing park boundary which is thus retained. There is no detailed knowledge of the numbers and.movements. of Ngorongoro. wildebeest and zebra. which are said to go north on both sides of Lemuta. The evidence of game tracks supports the assumption of henvy game movements across the BanagiSoitayai road, cast of the Magungu river. For this reason the boundary Lemuta-Grumechen is chosen as maintaining in part this line of movement, leaving the castern part, including the 
Angata Kiti, which Masai have tried to deny to wildebeest, for pastoral development. The third and principal weakness of the present data is the insufficient information about numbers of wildebeest and other game known to go north towards Bologonja and Mara rivers along a corridor some thirty miles wide west of the provincial boundary. There is general agreement that there is here a very important area for game movements in general. In addition, Kenya authorities believe it to be a corridor for plains animals moving between the Mara National Reserve and the Serengeti. It is tsetse bush and it is therefore recommended that it be maintained as a game reserve until satisfactory evidence of its possible importance, or otherwise, is obtained.

If the area thus defined is to be treated as National Park, it will be necessary ultimately for the Masai pastoralists to be cxcluded. On this question there is much to be said for regarding the provincial boundary as the border of Masai-land. If the existing pastoralists are for the present to continue to use the park grazing, they should do so under licence as suggested earlier (see Section 3) and dependent on good behaviour. There should be stated penalties for fire damage and tree-felling.

It is recommended that Masai pastoralists should be wholly excluded from the Moru area and (Section 7) Magadi Lake should be the approximate southern stock limit if the present use of the Laibor-doroto water-holes is allowed. For pastoralists coming north or west from the southern boundary, the Meira Mrvei and Engaremong water-holes should be an immediate limit of bomas. $A$ stock boundary here would need to be settled on the ground. It would be desirable that at an carly date licensed grazing in the park should cease inside or near the general line of the Olduwai, continued west, and Magungu rivers, allowing access to the following important and customary water-holes: Engare Nanyuki, Oljoro Laiser, Olduwai series of wells, MIeirn MIwei and possibly Engaremong. In the extreme west of the delimited area attempts at cultivation are already encroaching on the vital areas near and south of Handajega. The removal of these cultivators appears to be urgent, more so than the compensation of the population west of the Mwanza-MIusoma road. No human beings, other than poachers, were seen in the Duma river or upper Simuyu valleys. There is much poaching here suggesting that this would be a good site for controlled meat exploitation.

It should be recognized that the Grumeti plains, the Handajega corridor and the Moru concentration area are essential parts of the present game movements and therefore must be an integral part of a National Game Park. 
The main boundary problems in the Crater Irighlands are two, assuming that it is decided to retain the present Ngorongoro National Park Camp. The more important one is that of maintaining the corridor for game movements from the north-west of the Ngorongoro Crater to the plains. This would presumably have to follow the general line of the existing road to the crossing of the Olduwai Gorge. If the rocky south-western edge of the Olbalbal is taken as one boundary to that point, the other should

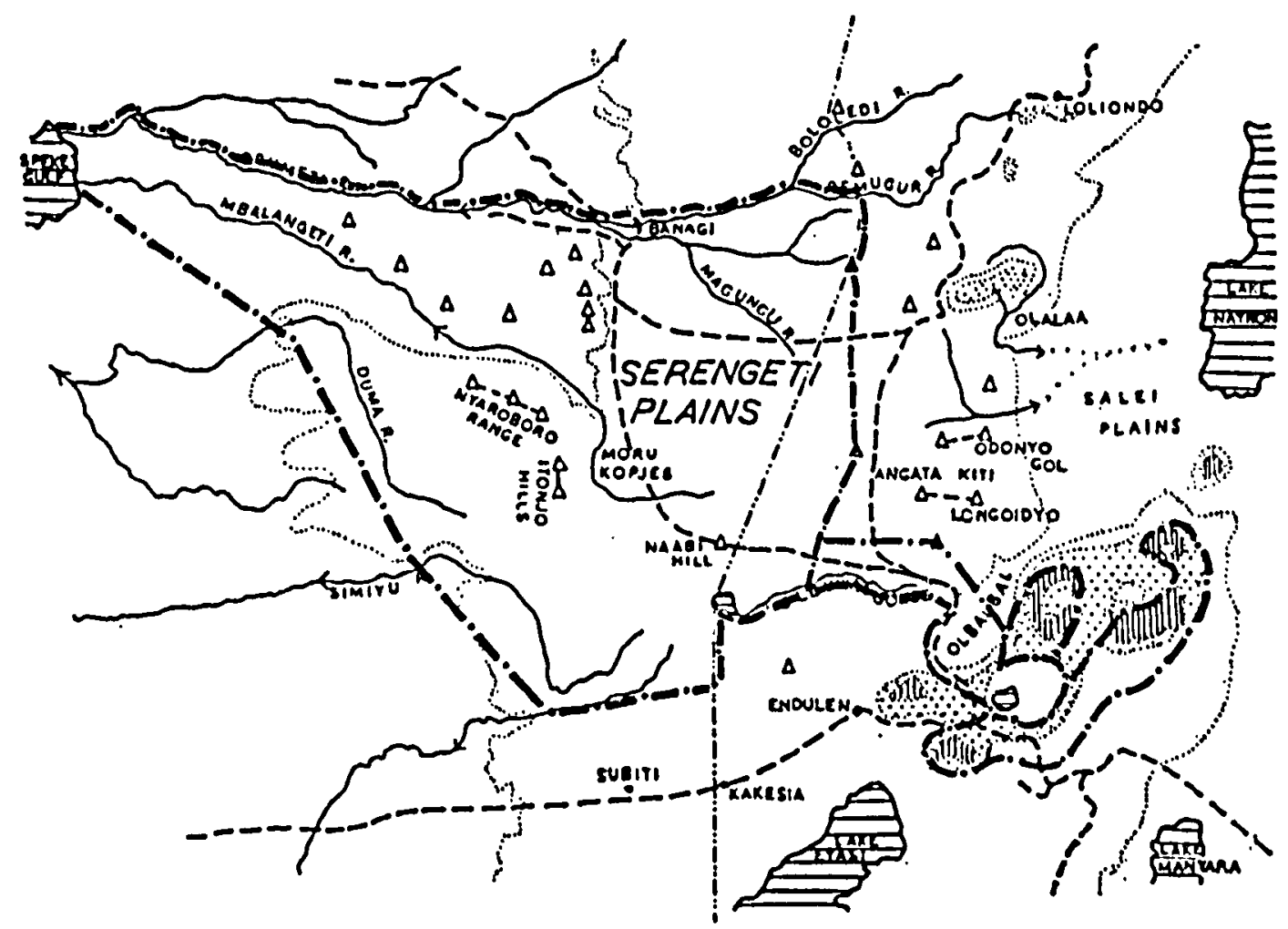

7. The boundaries of the areas suggested for game reservation, water and forest conservation in the Crater Highlands, and the corridor connecting with the main plains area. The arens outside these boundaries are recommended for pastoral development.

be approximately from a point about four or five miles north of the track junction at Windy Gap to the Olbalbal pond and thence to Olongoidyo and west along the line to Naabi. The southern boundary could be the Olduwai Gorge. The attempt might be made to maintain this as a "special game area ", but it will require severe limitation of human activity, particularly on the crater rim. No information is available about possible game movements south of the Olduwai.

The sccond problem in the Crater Irighlands is that of maintaining satisfactory boundaries around the water catchment 
areas. It is recommended that these in general should be protected from fire and cattle grazing and maintained and developed as forest and game reserves. A fire-break boundary thus seems to be indicated; it would need to be sited on the ground. The area "B" given as National Park in the White Paper is insufficient for the purposes of water conservation. It omits three important catchment areas : those of the Engare Rong, the Munge river (Olomoti Crater) and the spring on the southern slopes of Olomoti ; these should be included. 
Section 11

\section{RECOMMENDATIONS}

The following recommendations are made :-

(1) That a National Park, primarily for game preservation, be maintained in the Central and Western Serengeti, including the Moru area, with boundaries as given in Section 10.

(2) That a National Park for game, indigenous forest and water conservation be maintained in the Crater Highlands with boundaries as described in Section 10.

(3) That a connecting corridor with limited human access will be necessary between Ngorongoro Crater and the central plains, if the Ngorongoro Crater Camp is to be maintained as a tourist attraction.

(4) That arrangements be made for the early exclusion of pastoral occupation from the National Parks.

(5) That systematic attempts be made to develop the Masai-occupied territories particularly in regard to water (conservation and distribution) and grassland and range management.

(6) That a rescarch unit be set up to study the problems of game and habitat conservation. 


\section{Section 12}

\section{ACKNOWLEDGMENTS}

In concluding this report, I must cxpress my very great appreciation of the help so freely given to me by all concerned with the Serengeti. Particular mention must first be made of those who shared in the survey. The Government of Tanganyika generously made available Mr. H. F. I. Elliott, a senior member of the Secretariat, who made all the local arrangements and was the mainstay of the survey. His intimate knowledge of the area and wide experience, both as an ornithologist and as a former district officer, made his presence throughout as invaluable as it was welcome. Dr. P. J. Greenway, Keeper of the East African Herbarium, and Mr. G. H. Swynnerton, Chief Game Warden of Tanganyilka, were also most valuable members of the survey, bringing to it unrivalled knowledge of the plants and animals respectively which allowed a great deal to be seen and appreciated in the minimum of time. To them must be added the name of Mr. Donald Ker, who led the safari into the Western Serengeti and gave us the benefit of his unrivalled knowledge of the area and its game. Finally, it would have been impossible to have seen much of so large an area and of the game concentrations without the generous assistance of Mr. J. M. Hunter, of Oldeani, who flew over large areas of inaccessible country with me. To all of these the most sincere thanks and acknowledgments are due.

Special acknowledgment should also be made to the Government of Tanganyika for making available so many facilities of every type and for the same reason, to the National Park Trustees, and in particular the Chairman, Mr. N. H. Vicars Harris, and the Director, Licut.-Col. P. G. Molloy, all of whom were most generous and helpful. We had the advantage also of the great field experience of Mr. R. Hewlett, the retiring Warden of Ngorongoro, and Mr. P. E. Brambell, lately Game Ranger at Banagi. For all this help I am extremely grateful.

More specialized assistance was also frecly given. Mr. W. E. Calton, the Government Chemist, gave us maps and first-hand information on Tanganyika soils and arranged for analyses to be done. Mr. W. A. Guthrie, Director of Water Development and Irrigation, gave us details and maps concerning recent field work by his department. Mr. Mr. T. Friend, of the East African Agricultural and Forestry Research Organization, carried out the water analyses; Mr. I. B. Pullon, of the Tanganyika Veterinary Service, provided much detailed information on 
veterinary matters, and Mr. J. Glover, of the East African Agricultural and Forestry Research Organization, Mguga, gave maps and information on rainfall probabilities. The East African Meteorological Department was equally generous in extracting data about rainfall and evaporation. I owe much to Mrs. J. P. Newbould, both for soil analyses and map preparation. It will be appreciated that only by this wide and unselfish co-operation could such a survey be completed in a short time.

Those who in other ways contributed assistance and advice are almost too numerous to mention, but thanks and acknowledgment are due to the following: Mr. G. Ashley, Mr. Allan Brooks, Mr. R. Elliott, Dr. N. M. Hall, Mr. C. W. Hodgson, Dr. L. S. B. Leakey, Mr. A. J. R. MacEwan, Captain MI. S. Moore, V.C., Dr. H. C. Percirn, Dr. E. Piercy, Dr. E. W. RusselI, Mr. Keith Thomas, Mr. Miles Turner, Mrs. Verdcourt (Librarian of the E.A.A.F.R.O.), Colonel H. Weston and Mr. A. C. Woolland. 


\section{LIST OF DOCUMENTS CONSULTED}

1. The Screngeti National Park. Legisl. Council Tanganyika, Sess. Paper No. 1, 1050.

2. Mremorandum by the Board of Trustees of the Tanganyika National Parks to the Committec of Enquiry, 1050.

3. Minority Report by Mr. C. J. W. IIodgson, 1050.

4. Memorandum submitted to the Serengeti National Park Enquiry Committec by ex-members of the late Board of Management.

5. Memorandum on the Serengeti National Park problem submitted by the Kenya Wild Life Socicty, 1050.

0. Memorandum from the Chairman, Board of Trustees Tanganyika National Parks, 1050.

7. Tanganyika and Kenya Wild Life Socicties : Comments on the Tanganyikn Government's White Paper entitled "The Serengeti National Park", 1050.

8. The Secretary, Fauna Preservation Society, London. What of the Serengeti ? Oryx, III, 6, 1050 .

D. Lee MI. Talbot. Report on a brief visit to the Screngeti National Park, 105. Internat. Union for P'rolection of Nature, 1050.

10. G. A. Petrides. Report on Kenyn's wild life resources and the National Parks, 1054. Publ. Royal Nat. Parks Kíenya.

11. II. St. J. Grant. Report on human habitation of the Serengeti National Park, 105.1. Tang. Nat. Parlis.

12. J. D. Snowdon. The grass communities and mountnin vegetation of Uganda. Crown $\Lambda$ gents for the Colonies, Nillbank, 1053.

13. D. C. Edwards. Grass-burning. Emp. J. Exper. Agric., 10, $210,1013$.

14. E. J. Wayland and N. V. Brasnctt. Soil crosion and water supplics in Uganda. Mem. IV, Geol. Surv. Uganda, 1038.

15. II. C. Percira. The physical importance of forest cover in Enst African Ilighlands. E.A. Agric. J., 19, 233, 105.4.

10. Fritz Jneger. Das hochland der reisenkrnter und die umliegenden hochlander Deutsch.Ostnfrikn, 1000-7. Mill a. d. Deutsch Schutzgebieten. Tiel I u. II, Erg. Nr. 4 und 8, 1011-13.

17. C. Gillman. $\Lambda$ hydrographic reconnnissance into parts of MInsai-land. Water Consullant's licport No. 1, 1038. Govt. Printer, Dar es Salnam.

18. - $\Lambda$ reconnnissance survey of the hydrology of.Tnnganyika Territory in its geogrnphical settings. Water Consullant's Reporl No. 0, 10.10. Govt. Printer, Dar es Salanm.

10. II. S. Reynolds and J. W. Bohning. Effects of burning on a desert grassshrub rnnge in Southern Arizona. Ecology, 37, 700, 1050.

20. W. M. Jolunson. Effect of grazing intensity on vegetation in Central Colorado. Ecology, 37, 700, 1050.

21. D. C. Edwards. II, Vegetation in relalion to soil and water conscrvation in East Africa, p. 28. NInngement and Conservation of Vegetation in Africn. 13ull. No. 41, Commonzv. Bhur., Pastures and Ficld Crops, 1051.

22. II. J. Van Rensburg. III, Conservation of vegetation in Tanganyika Territory, p. 4.4. Ibid. 
23. A. Bogdan. Bush clcaring and grazing trial at Kisolion, Kunyc. E.A. Agric. J., 19, 253, 105.1.

24. II. Olivicr. Engincering developments of hydropotentials in relntion to climate. Ph.D. 'Thesis, London University, 105.4.

25. C. W. Thornthwaitc. An appronch toward a rational classification of climate. Geogr. Rev., 38 (1), 55, 1018.

20. II. IV. Sansom. The climatc of E. Africa. Mem. L. African Mct. Dept., 111, No. 2.

27. II. F. Birch and M. T. Friend. The organic-matter and nitrogen status of East African soils. J. Soil Sci., 7 (1), 156, 1056.

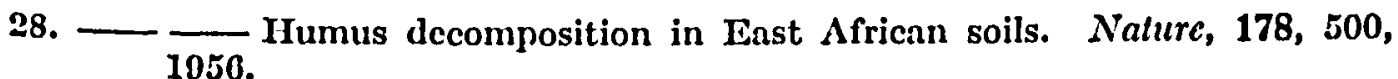

20. J. Glover, P. Robinson and J. P. IIenderson. Provisional maps on the reliability of annual rainfall in East Africa. Q.J. Roy. Meteor. Soc., 80, 602, $105 \%$.

30. J. Glover and P. Robinson. Map of East Africa showing probability of obtaining less than 20 inclics of rainfill per year. Dept. of Lands and Surveys, Dar es Salaam, 1055.

31. Maps 2 and 3. East Africa, population, tsetse fly and rainfull. Roy. Comm. East Africa, 105.

32. Geological map of East $\Lambda$ frica. Dept. Lands and Survey, Dar cs Salanm, 1052.

33. E.A. Met. Dept. Map showing mean annual rainfall of British East $\Lambda$ frica. Govt. Printer, Nairobi, 1053.

34. E.A. Agric. Res. Institute. Soil map ; Tanganyika Territory. Dept. Lands and Mlines, Dar es Salaam, 10.47.

35. W. E. Calton. Experimental pedological map of Tanganyika. Dept. Lands and Surveys, Dar es Salnam, 1055.

30. C. Gillman. Tanganyika Territory vegetation types (map). Geog. Rev., 39, $1,10.40$.

37. G. $\Lambda$.'Petrides. Big game densities and range cnrrying capncities in Fast Africn. 21st N. Amer. Wild Life Conf., New Orleans, 1050.

\section{UNPUBLISIIED DOCUNIENTS}

II. St. J. Grant. The Mnsni in the Nationnl Park (draft), 1050.

II. B. IIodgson (D.O., Musomn). Memorandum on Scssionnl Pnper No. 1 of 1050 of the Legislative Council : 'The Serengeti Nationnl Pork. 1050.

I. B. Pullon. Datn on livestock populations, Masailnnd. Dept. of Vet. Services, 1050.

T. O. Robson. Report on the grasslands of the Ngorongoro Ilighlunds. Soil Conservation Service, 1055.

IR. IRlimncki. Report on the geological and geophysical investigntions for boreholes around the Ngorongoro-Lemngrut Cruters, Nunbi nnd Moru.

D. IKeith Thomns, Some notes on the migratory gnme animals of Serengeti Plains (1053).

G. Nushby. Gnme nud game movements in the Nationnl Park, 1055 (in draft). National Park Oflicers. Summary of game and stock movements within the Park (105.b). 
130 Ecological Survey of the Serengeti National Park

P. G. Molloy. Notes on the Munge Stream (with comments by D. C. Masai).

A. C. Brooks. Studics into the life-history and ecology of Thomson's gazelle (G. Tomsonii) in Tanganyika. Report to Colonial Research Service, 1057.

II. R. IIerring. Report on Ngorongoro-Olmalassin Forest Reserve, Sept.-Oct., 1020 .

- Report on Oldonyo-Olimoti with special reference to protection of forests and water conservancy, 1030. 
